\title{
COMPLEMENT TENSE IN CONTRAST: THE SOT PARAMETER IN RUSSIAN AND ENGLISH
}

\author{
ATLE GRØNN AND ARNIM VON STECHOW \\ University of Oslo and Tübingen/Konstanz
}

\section{ABSTRACT}

In an sот-language like English, "past under past" may have a simultaneous interpretation, i.e., we have temporal agreement. In a non-soт language like Russian, we get the shifted interpretation. In English, the temporal morphology of the embedded verb can be determined by the matrix tense via a binding chain through verbal quantifiers such as 'say' or 'think'. In Russian, these attitude verbs break the binding chain, hence the morphology of the embedded verb is determined locally by an embedded relative PRESENT or PAST. The main tense of an attitude complement will be a semantically empty PRO. We propose that the difference between English and Russian is derived from the sот-parameter, saying that a language $L$ is an sот-language if and only if the verbal quantifiers of $L$ transmit temporal features.

The paper gives a precise formulation of the syntax and semantics of the constructions involved. The essential idea is that temporal features are transmitted via semantic binding; following the soт-parameter, verbal quantifiers may or may not act as barriers for feature transmission.

The paper takes up a recent challenge by Daniel Altshuler and Olga Khomitsevich against existing accounts: verbs of perception and, occasionally, attitude verbs and factive verbs in Russian may express simultaneity by "past under past". For attitude verbs, we show that the problem is in fact nonexistent when the complement is imperfective. Concerning factives, we argue that the complement tense is an independent de re past. Finally, perception verbs are normally not verbal quantifiers and hence not subject to the sOT-parameter.

\section{[1] INTRODUCTION TO COMPLEMENT TENSE}

The role of tense is ubiquitous in natural language, yet many phenomena pertaining to subordinate tense remain to be properly investigated and understood. In this paper we will provide a semantically motivated explanation - the soт parameter - which is intended to capture the difference between tense agreement and non-agreement languages. In other words, we explain the distribution of complement tense in sequence-of-tense languages (notably Germanic and Romance languages) and non-sequence-of-tense languages like Russian. The proposal restores 
the traditional view of Russian as a non-soт language despite the challenging data, notably from factives and perception verbs, recently discussed by Altshuler and Khomitsevich. In future work, we intend to extend the theory to capture adjunct tense, as well.

In this section, we will introduce the sот parameter, our general tense architecture, and some key notions central to the theory - dependent (vs. independent) tense, verbal quantifiers, and zero (vs. fake) tense. In section [2], we will introduce the basic patterns found in Russian and English complement tense. Our methodology is based on retrieval of authentic data from parallel corpora. Next, in section [3], we give a formal implementation of our theory. Finally, in section [4], we show that Russian "past under past" with imperfective complements and/or matrix factives and perception verbs are compatible with our theory and the proposed sot parameter.

\section{[1.1] The SOT parameter}

The contrast in (1) illustrates the difference between sequence of tense found in Germanic languages, and non-sequence of tense characteristic of Russian ${ }^{1}$.

(1) R On skazal PAST-PF $_{\text {, čto živet }}$ PRES pod Moskvoj. (Viktor Pelevin, "Pokolenie P")

E He said he was living just outside Moscow.

$\mathrm{N}$ Han fortalte $\mathrm{PAST}_{\mathrm{P}}$ at han bodde $\mathrm{PAST}_{\mathrm{T}}$ utenfor Moskva.

Tenses express relations between times: backward shift (precedence), simultaneity (overlap), or forward shift (succession). Russian apparently represents the most natural form-meaning mapping. The embedded tense in (1R) is a (relative) present tense - expressing simultaneity with the higher past tense of the verbum dicendi. In our feature system, the present tense morphology is licensed by a relative PRESENT Operator in complements of attitude verbs in Russian (Ogihara 1989), (Kusumoto 1999), (Schlenker 1999) and (von Stechow 2003). Since the feature transmission is done locally in the complement in non-soт languages, Russian morpho-syntax neatly matches the semantics in this domain. (We speak of the feature "present" originating with the semantic PRESENT and transmitted to the finite verb; the mechanism will be explained in detail below, notably in section [3]).

In sequence-of-tense languages like English and Norwegian, morphology is not in a one-to-one relation with semantics due to the phenomenon of temporal agreement: the past tense morphology ("was" (Eng.), "bodde" (Nor.)) in the complement in $(1 \mathrm{E}) /(1 \mathrm{~N})$ is semantically void and simply agrees with the past tense operator in the matrix. This fact requires syncategorematic rules (here: long-

[1] $\mathrm{E}=$ English, $\mathrm{F}=$ French, $\mathrm{G}=$ German, $\mathrm{N}=$ Norwegian, $\mathrm{R}=$ Russian. 
distance transmission of temporal features following the sот parameter, i.e., nonlocal binding).

The difference between English and Russian is tentatively illustrated in Figure 1.

PAST He said $\varnothing$-tense he was living outside Moscow (English)

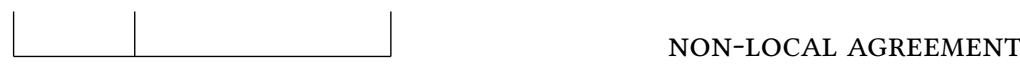

PAST On skazal čto $\varnothing$-tense PRES živet pod Moskvoj (Russian)

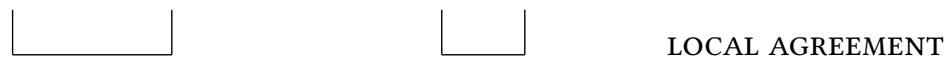

FIGURE 1: Local vs. non-local agreement of tenses

We adopt a feature theory whose conceptual attractiveness comes from the explicit encoding of every detail in the morpho-syntax and the corresponding dependence on semantic operators. The system gives us a precise formulation of the syntax and semantics of the constructions involved. The basic machinery is the following (more details are given below in section [3]): Every verb has a temporal argument. The temporal argument is satisfied by a variable coming from the tense morphology with an uninterpretable feature. The interpretation of this variable is determined by a binding relation with a SEMANTIC OPERATOR having a corresponding interpretable feature. With complements in sот languages we get agreement throughout the c-command domain, with a semantic operator checking several instances of the same uninterpretable feature (a kind of Multiple Agree). In non-sot languages, the morphology is licensed locally by a corresponding semantic operator.

Khomitsevich (2007) adopts a framework with feature checking as well but seeks primarily a syntactic explanation of subordinate tense data. Following the work of Abusch (1994b), Schlenker (1999), von Stechow (2003) among others, we focus on the semantics of the matrix verb in our explanation of the data.

The difference between English and Russian is derived from the soт parameter:

A LANGUAGE L IS AN SOT LANGUAGE IF AND ONLY IF THE VERBAL QUANTIFIERS OF L TRANSMIT TEMPORAL FEATURES. (The SOT parameter)

In English, the temporal morphology of the embedded verb is determined by the matrix tense via a binding chain through verbal quantifiers such as "say". In Russian, "skazat" ("say") breaks the binding chain. The morphology of the embedded verb is determined by an embedded relative PRESENT or PAST. 
The sот parameter gives the right predictions and explains the different distribution of subordinate tenses in sот and non-sот languages such as the expression of simultaneity in (1) as "past under past" in soт and "present under past" in non-sot languages.

\section{[1.2] Architecture of tenses}

For an easier understanding of our paper, the following remarks on our view of the architecture of tenses may be helpful. Tenses have the structure schematically presented in Figure 2.

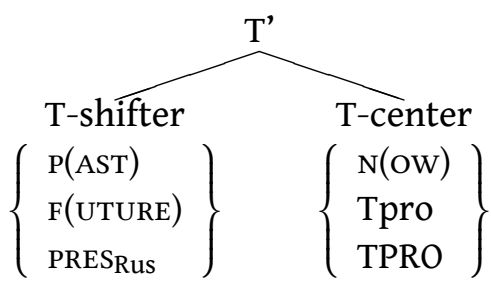

FIGURE 2: Architecture of tenses

Partee (1973) proposed to treat tenses in general as PRONOUNS - deictic or anaphoric. In our theory, a semantic tense consists of an obligatory TEMPORAL PRONOUN (T-center, perspective time, local evaluation time) and an optional SHIFTER. The pronoun $\mathrm{N}(\mathrm{OW})$ is deictic and refers to the speech time. Tpro is an anaphoric pronoun bound by a higher tense. TPRO is a semantically empty pronoun and must be moved for type reasons. This movement creates a $\lambda$-operator binding the temporal variable in the T-center. TPRO is what has been called ZERO TENSE ( $\lambda$-tense) in the literature, cf. (Kratzer 1998), (von Stechow 1995).

The shifters are existential quantifiers based on the temporal center and temporal relations such as "before", "after" and "identical" and possibly others. P(AST) means "there is a time before the temporal center T", F(UTURE) means "there is a time after the temporal center T" and PRES Rus $_{\text {means "there is a time identical }}$ with the temporal center T". We assume that the temporal center is the same in all languages. We further think that the quantifying force of the shifters is always existential, but the relations may vary across languages: for instance, English has no PRESRus, German and Japanese use the relation "not before" for the present; there might be temporal overlap, temporal inclusion, "no after" and others.

If the center is $\mathrm{N}$, we have a DEICTIC TENSE; this is the tense found in the matrix clause. If the center is Tpro, we have an ANAPHORIC TENSE bound by some higher tense; this kind of tense is found in relative clauses and other adjuncts. If the center is TPRO, we have a BOUND TENSE, i.e., a temporal variable locally bound by a $\lambda$-operator. 


\section{[1.3] Dependent vs. independent tense}

The sот parameter applies to dependencies between matrix tense and subordinate tense. Obviously, tense in subordinate clauses often has a different status from matrix tense, since the former can be DEPENDENT on the latter. In deictic tenses, the pronominal T-center refers to the now of the context, but in dependent tenses, the pronominal center may be anaphoric, as in relative clauses, or $\lambda$-bound as in complements.

The distinction between independent (deictic) and dependent tense is crucial in our survey. When we consider complex data from subordinate tense, we should keep in mind the possibility of the lower complement tense being independent of the higher matrix. In such cases, the morphology of the subordinate tense is licensed by the speaker's deictic now in the utterance situation or by a de re past, and the sot parameter does not directly apply to the construction.

The difference between dependent and independent tense is illustrated below:

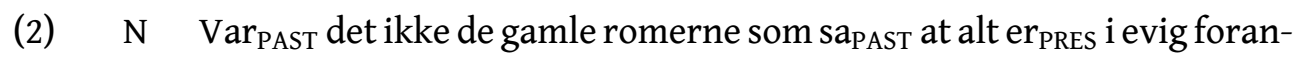
dring? (independent) (Nikolaj Frobenius, "Latours katalog")

E Wasn't it the ancient Romans who said that everything was in a process of eternal flux? (dependent)

F Les vieux Grecs ne disaient-PAST-IMPF-ils pas que tout est-PRES en perpétuel changement? (independent)

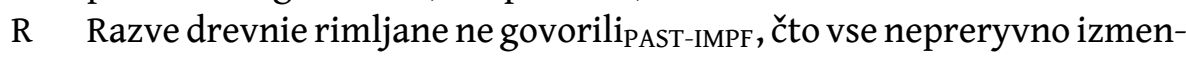
jaetsja ares? (dependent or independent)

The embedded present in the Norwegian original and French translation requires an independent interpretation ${ }^{2}$ : the complement reports a universal truth which was true at the time of the ancient Romans and remains true for the author at the moment of writing - a kind of "double access" interpretation. Arguably, we have an independent de re extended Now in the complement (Abusch 1997). For soT languages like Norwegian and French, a dependent interpretation in $(2 \mathrm{~N}) /(2 \mathrm{~F})$ would have required tense agreement, hence past tense morphology both in the matrix and complement. This tense agreement is precisely what we find in the English translation.

Concerning the Russian translation, we cannot distinguish between a dependent and independent ("double access") reading. The surface syntax in (2R) matches the Norwegian original, but since Russian is not a tense agreement language, the present tense in the Russian complement remains indistinguishable between a relative present (a simultaneous interpretation dependent on the matrix) and an independent present.

[2] Germanic and Romance languages do not have a relative PRESENT of the Russian kind, see section [3.4]. 


\section{[1.4] Verbal quantifiers}

Verbal quantifiers quantify over times ${ }^{3}$ (e.g. the future auxiliary will) or worldtime pairs (e.g. verba dicendi). In order to avoid temporal paradoxes analysed in (von Stechow 1981), (Heim 1994a), (von Stechow 1995), among others, attitude verbs cannot be simply quantifiers over worlds.

The paradox is illustrated in the following sentence:

At 5 o'clock Mary thought it was 6 o'clock.

The sentence is coherent and makes perfect sense although Mary is obviously wrong about the time in the context of (3). However, if the complement is analysed in the Hintikka-style as a proposition (set of worlds) we end up attributing the absurd belief to Mary that " 5 o'clock $=6$ o'clock".

The solution is to let attitudes quantify over worlds and times (and individuals, neglected here). Hence the complements must be properties of times, whose highest semantic tense is a ZERO TENSE (a temporal abstract), cf. (Kratzer 1998). Our semantics for attitude predicates follows the insights of Lewis (1979):

【believe】 type (s(it)),(i(et)) $=\lambda w \lambda P_{\text {sit })} \lambda t \lambda y .\left(\forall w_{1}\right)\left(\forall t_{1}\right)\left[\left(w_{1}, t_{1}\right)\right.$ is compatible with everything $y$ believes of $(w, t)$ in $w$ at time $\left.t \rightarrow P\left(w_{1}\right)\left(t_{1}\right)\right]$

In order to understand complement tense under attitudes, it must be stressed that the semantics of attitudes gives us an abstraction over the highest temporal variable in the complement. This subtle fact is a permanent source of confusion, and we will return to this point below.

We will not try to give an exhaustive list of verbal quantifiers in natural language, ${ }^{4}$ but we will make one demarcation in the next subsection.

\section{[1.5] Zero tense vs. fake tense}

A ZERO TENSE embedded under an attitude verb is semantically void, it does not have any meaning. However, some caution is called for. Consider the following sentence, with an embedded counterfactual:

(5) E John believes PRES that Mary would ${ }_{\text {PAST-MODAL }}$ come $_{\text {INF }}$ if she was PAST $_{\text {PT }}$ invited $_{\text {PART. }}$.

G John glaubt $t_{\text {PRES }}$ dass Marie käme PAST-SUBJ $_{\text {, wenn sie eingeladen }}$ PART würde PAST-SUBJ

R Vanja verit $t_{\text {PRES }}$, čto Maša prišla PAST-PF $_{\text {bysUJ.PART, esli bysUBJ.PART }}$ ee priglasili PAST-PF. $_{\text {. }}$

[3] i.e., "there is a time in the future/past ...". Formally, these verbs embed a lambda abstract over times.

[4] The future auxiliaries "will/would" (Eng.) and "budet" (Rus.) as well as their mirror operator - the perfect auxiliary "have" (Eng.) - are quantifiers over times, hence verbal quantifiers in our understanding. 
Although the embedded verbs have past morphology, it is obvious that this is not a real past tense, since the embedded counterfactual is not evaluated at a time preceding the subjective now but at a time succeeding the subjective now. The embedded tenses cannot be in a relation of temporal agreement with the matrix tense (attitude verb), since the latter is in the present tense. So (5) is a case of what Iatridou (2000) calls FAKE PAST: past tense morphology does not point to anteriority. The verb form does not have its normal temporal feature, but a feature pointing to a subjunctive interpretation. This is what we see more clearly in German (5G) and Russian (5R), where the fake past is translated by forms of subjunctive past (Konjunktiv 2), a mood used in counterfactuals. In English and many other languages, the subjunctive is lost and we have a sort of tense-mood syncretism. Thus, fake tense needs a different treatment, and is not to be confused with zero tense.

The example in (5E) shows that there is no 1-to-1 correspondence between semantic features and morphology. The same morphology may encode different semantic features. ${ }^{5}$ For the purposes of this study we will rely on an intuitive and informal distinction between zero tense and fake tense exemplified above. Verbal quantifiers which transmit their mood features as fake tense morphology (e.g. the counterfactual operator would) are not directly relevant for the sот parameter.

\section{[2] COMPLEMENT TENSE IN PARALLEL AND CONTRAST}

The examples ${ }^{6}$ in our study are naturally occurring data taken from two searchable parallel corpora developed at the University of Oslo - the Oslo Multilingual Corpora (OMC) and the RuN corpus, as well as the English-Russian parallel corporus provided by the Russian National Corpus. The first item listed in the examples is the original source - typically a Norwegian or Russian fiction text - then follow the translations made by professional translators. Our main focus will be on Russian and English, but we will occasionally also comment on examples from other languages, notably Norwegian, German and French.

\section{[2.1] Simultaneous interpretation under past attitudes}

The simultaneous interpretation under past attitudes is expressed by a "past under past" configuration in sот languages and "present under past" in non-soт languages.

[5] The opposite is also true: the same semantic feature may be encoded by different morphological means even in one single language. To give an example: the German past form war 'was' and the present perfect form bin gewesen 'have been' mean the same.

[6] Glossing is reduced to a minimum in the examples, making use of the following abbreviations: AUX = auxiliary, $\mathrm{COND}=$ conditional mood, FUT = future tense, IMPER = imperative mood, IMPF = imperfective aspect, $\mathrm{INF}$ = infinitive, $\mathrm{PART}$ = participle, $\mathrm{PF}=$ perfective aspect (including le passé simple in French), PRES $=$ present tense, REL.PRON = relative pronoun, SUBJ = subjunctive, SUBJ.PART = subjunctive particle. 
(6) N De sa $a_{\text {PAST }}$ at Hanna $\operatorname{var}_{\text {PAST }}$ Stines unge. (Herbjørg Wassmo, "Dinas bok")

E They said Hanna was Stine's child.

G Die Leute sagten ${ }_{\text {PAST }}$, daß Hanna Stines Kind war PAST $_{\text {. }}$.

F On disait PAST-IMPF $_{\text {que Hanna appartenait }}$ PAST-IMPF à Stine.

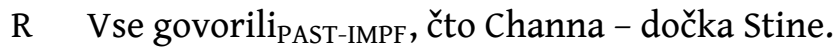

sот languages include Germanic languages (here: English, German, and Norwegian) and Romance languages (here: French). The present tense in the complement of the Russian sentence (6R) is a zero copula, cf. Figure 3.

PAST They said $\varnothing$-tense Hanna was Stine’s child (English)

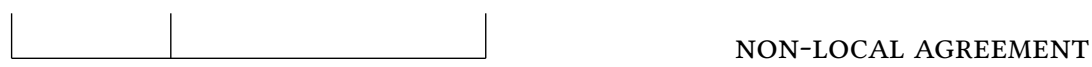

PAST Vse govorili čto $\varnothing$-tense Ch PRES $\varnothing$-copula dočka S (Russian)

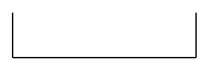

LOCAL AGREEMENT

FIGURE 3: Simultaneous interpretation under past attitude

The intensional nature of attitude verbs shows up in German, in which the embedded complement can display different versions of the subjunctive, instead of the expected "past under past". Accordingly, German attitude verbs optionally have a feature like sUBJUNCTIVE, which is transmitted to the complement verb. For instance, in $(7 \mathrm{G})$, the subjunctive present is used in German:

(7) N Han sapAST at han ikke kjente $e_{\text {PAST }}$ noen ting.

(Nikolaj Frobenius, "Latours katalog")

E He [...] said he couldn’t feel anything.

$G \quad$ Er sagte $_{\text {PAST }}$, er spüre SUBJ $_{\text {nichts. }}$ nict

F Il m'a PRRES-AUX dit $_{\text {PART }}$ qu'il ne sentait PAST-IMPF $_{\text {rien. }}{ }^{7}$

$\mathrm{R}$ On skazal ${ }_{\text {PAST-PF }}$, čto ničego ne čuvstvuet ${ }_{\text {PRES. }}$

If the matrix tense is expressed by a present perfect in an soт language, we expect to find a present tense in the complement - in agreement with the present auxiliary of the matrix. This pattern is found in the Norwegian translation $(8 \mathrm{~N})$ - "present under present_perfect" - which contrasts with the English (8E) "past under past".

[7] The French translation in (7F) poses interesting questions. The auxiliary $a$ has present morphology, but it licenses the past morphology of the embedded sentait. In our theory we will have to express this by stipulating the feature combination uN, iP for the auxiliary $a$. In this respect, French (and other Romance languages like Italian) differs from English. 
(8) $\mathrm{R}$ Ty ne skazal ${ }_{\text {PAST-PF, }}$, čto ljubiš' ${ }_{\text {PRES }}$ menja ...

(Ljudmila Ulitskaja, "Medeja i ee deti")

E You didn't say you loved me.

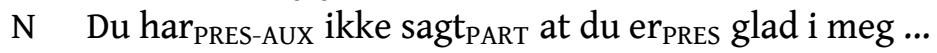

In this respect, it should be noted that feature transmission carries on through non-finite verb forms like past participles as in (8N) or the infinitive "say" in (8E).

The translator's choice of lexical aspect (Aktionsarten) or grammatical aspect can influence the tense configuration, blurring the expected "past vs. present" dichotomy between sот and non-sот. The following example illustrates this point.

(9) N Folk sapAST at ville dyr bebodde PAST $_{\text {Pemakkene. }}$

(Nikolaj Frobenius, "Latours katalog")

E It was rumoured that wild beasts had taken up residence there.

$G \quad$ Man erzählte $e_{\text {PAST }}$ sich, daß inzwischen wilde Tiere in den Zimmern hausten PAST $_{\text {. }}$

$\mathrm{R} \quad$ Ljudi govorili $\mathrm{PAST}_{\text {-IMPF }}$, budto $\mathrm{v}$ dome poselilis' ${ }_{\text {PAST-PF }}$ dikie zveri.

The Norwegian original in (9N) displays "past under past" with a stative complement verb "bebo". The German translation follows this pattern, but the English translation makes use of the inchoative VP "take up residence", which excludes a simultaneous interpretation with the matrix. Hence, the English construction displays an additional second layer of past tense ${ }^{8}$ : the past tense suffix of "had" is empty and agrees with the matrix past, while the perfect operator - the lexical content of "have" - converts the VP into a stative. This gives the wanted result: The resultant state of the VP "take up residence" is simultaneous with the matrix event. Note that also the Russian translator has chosen an inchoative perfective verb, a choice which requires a "past under past" in Russian.

The various strategies employed in the translations of (9) can be easily accounted for by our theory once we incorporate aspect - and we will do so in section [4] (see also section [2.4] for an analysis of eventive/perfective embeddings). The literature on зот has mostly been concerned with embeddings of stative and imperfective complements, where the opposition sot vs. non-sot is (apparently) more transparent in the canonical case of a simultaneous interpretation: "past under past" vs. "present under past". However, in section [4] we will address data in Russian which complicate this picture, notably constructions involving factive matrix verbs and perception verbs.

Below we give some examples with factives that correspond to the "expected" pattern for non-sot languages, i.e., "present under past" with a simultaneous in-

[8] But see some examples below. If the complement is eventive, a simple "past under past" construction in Germanic can often have a backward shifted interpretation. 
terpretation. ${ }^{9}$

(10) N Han visste PAST $_{\text {at hun sto }}$ PAST der. (Herbjørg Wassmo, "Dinas bok")

E He knew she was standing there.

$G \quad$ Er wußte PAST $_{\text {, }}$ daß sie dort stand PAST $_{\text {. }}$.

F Il savait $t_{\text {PAST-IMPF }}$ qu'elle était PAST-IMPF $_{\text {là. }}$

$\mathrm{R}$ On znal $\mathrm{PAST-IMPF}$, čto ona stoit $t_{\text {PRES }} \mathrm{u}$ okna.

(11) N Mor Karen gjennomskuet ${ }_{\mathrm{PAST}}$ at ferdighetene ikke var ${ }_{\mathrm{PAST}}$ så overvettes i tysk. (Herbjørg Wassmo, "Dinas bok")

E Mother Karen discovered that his proficiency in German and French was quite limited.

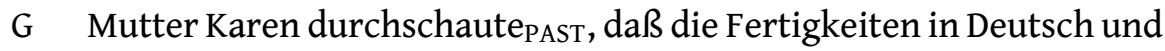
Französisch nicht überwältigend waren ${ }_{\text {PAST }}$.

F Mère Karen s'était ${ }_{\text {PAST-IMPF }}$ bien rendu $u_{\text {PART }}$ compte que ses connaissances en allemand et en français n'étaient $t_{\text {PAST-IMPF }}$ pas excessives.

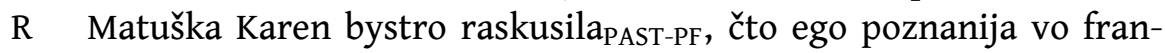
cuzskom i nemeckom ostavljajut $t_{\text {PRES }}$ želat' INF lučšego.

(12) N Mor Karen forsto PAST $_{\text {at Dina neppe kunne }}$ PAST-MODAL oppøves INF $_{\text {i }}$ i filosofiske diskusjoner. (Herbjørg Wassmo, "Dinas bok")

E Mother Karen sensed that philosophical discussions or theological topics were not the way to train Dina.

G Mutter Karen begriff ${ }_{\text {PAST }}$, daß Dina für philosophische Diskussionen und theologische Themen wenig Verständnis hatte $\mathrm{PAST}_{\text {. }}$.

F Mère Karen comprit ${ }_{\text {PAST-PF }}$ qu'on pouvait PAST-IMPF-MODAL $_{\text {'ifficilement }}$ entraîner $_{\text {INF }}$ Dina dans des discussions philosophiques ou théologiques.

R Matuška Karen ponjala ${ }_{\text {PAST-PF, }}$, čto Dina vrjad li možet $t_{\text {PRES-MODAL }}$ podnjat'sja $_{\text {INF }}$ do filosofskich diskussij ili bogoslovskich besed.

(13) N Mor Karen innsåPAST at Jacob måtte $\mathrm{PAST}$-MODAL til kyndig behandling. (Herbjørg Wassmo, "Dinas bok")

E Mother Karen realized that Jacob required expert treatment.

G Mutter Karen kam PAST $_{\text {zu }}$ der Einsicht, daß Jacob eine sachgemäße Behandlung brauchte $\mathrm{PAST}$.

F Mère Karen se rendit $t_{\text {PAST-PF }}$ compte que Jacob demandait ${ }_{\text {PAST-IMPF }}$ des soins qualifiés.

R Matuška Karen ponimala $a_{\text {PAST-IMPF, }}$, čto Iakovu trebuetsja $a_{\text {PRES }}$ umelaja pomošč'.

(14) R Medeja ponjala $a_{\text {PAST-PF }}$, čto emu očen' chočetsja $a_{\text {PRES }}$ pojti $t_{\text {INF }} s$ nej v ètot samyj "Kavkaz". (Ljudmila Ulitskaja, "Medeja i ee deti")

[9] See section [4.3] and our analysis of these cases. 
E Medea understood that he really was very keen to take her to this restaurant of his.

N Medea forstopAST at han hadde PAST $_{\text {Peldig lyst til å gå }}$ INF på dette "Kaukasus"-stedet sammen med henne.

Note that the distinction between factives and other verbs of attitudes such as verbs of speech can be quite subtle. In the context of (15) below, the factive verb "learn" means "be told" (+ a factive presupposition):

(15) N Latour lærte PAST $_{\text {at }}$ at det var PAST $_{\text {Pdannet å drikke }}$ INF suppe fra skålen. (Nikolaj Frobenius, "Latours katalog")

E Latour learnt that it was unseemly to drink soup from the bowl.

$G \quad$ Latour lernte $e_{\mathrm{PAST}}$, daß es ungezogen war $_{\mathrm{PAST}}$, Suppe aus der Schale zu schlürfen ${ }_{\text {INF. }}$.

F Ainsi Latour put PAST-PF-il apprendre $_{\text {INF }}$ que c'était $_{\text {PAST-IMPF }}$ manquer $_{\text {INF }}$ au bon usage que de boire INF $_{\text {la soupe à l'assiette. }}$

R Latur uznal ${ }_{\text {PAST-PF, }}$ čto neprilično pit' ${ }_{\text {INF }}$ sup iz miski.

[2.2] Forward shifted interpretation under past attitudes

A forward shifted interpretation may require the insertion of a covert future operator at LF in sот languages.

(16) E I asked what time the attack was to be and they said as soon as it was dark. (Ernest Hemingway, "A Farewell to Arms")

$\mathrm{R}$ Ja sprosil PAST-PF, $_{\text {, }}$ kotorom času načnetsja $\mathrm{FUT}_{\mathrm{FUF}}$ ataka, i mne skazali $_{\text {PAST-PF, }}$ čto kak tol'ko sovsem stemneet ${ }_{\mathrm{FUT}-\mathrm{PF}}$.

The covert future operator does not break the checking relation, as we see in Figure 4.

PAST they said $\varnothing$-tense as soon as it was FuT dark (the attack was to be) (English)

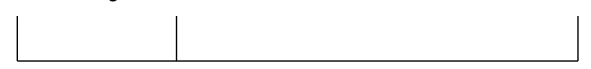

NON-LOCAL AGREEMENT

PAST skazali čto $\varnothing$-tense kak tol'ko FUT stemneet (Russian)

LOCAL AGREEMENT

FIGURE 4: Forward shifted interpretation under past attitude

Viewpoint aspect is not represented in Figure 4, but a full analysis requires two perfective like operators in the Russian sentence, one in the matrix and one in the complement. Perfective verbs with present tense morphology like "stem- 
neet - becomes dark" receives a future (and perfective) interpretation, since the combination $\mathrm{PF}(\mathrm{N})$ - perfective and present - is semantically inconsistent. Accordingly, the usual PF operator is replaced by a semantic tense FUT $_{\text {Rus }}$, which has its own feature iF. ${ }^{10}$

In example (17), the forward shifted meaning is explicitly conveyed by a modal or periphrastic construction in the complement of the sот languages. The Russian (17R) displays the familiar "perfective_future under past":

(17) N Dina sa $a_{\text {PAST }}$ at Tomas og hun skulle PAST-MODAL $_{\text {kjøre }}$ INFJacob over fjellet til doktor. (Herbjørg Wassmo, "Dinas bok")

E Dina announced that she and Tomas would drive Jacob across the mountain to the doctor.

$G$ Dina sagte ${ }_{\mathrm{PAST}}$, daß Tomas und sie Jacob über das Gebirge zum Doktor fahren INF $_{\text {w }}$ wirden PAST-SUBJ-MODAL $_{\text {. }}$

F Dina déclara ${ }_{\text {PAST-PF }}$ que Tomas et elle-même allaient $t_{\text {PAST-IMPF }}$ amen$\mathrm{er}_{\text {INF }}$ Jacob par la montagne chez le docteur.

$\mathrm{R}$ Dina skazala $a_{\text {PAST-PF }}$, čto oni s Fomoj otvezut ${ }_{\mathrm{FUT}}$-PF Iakova $k$ doktoru.

Verbs of control like "promise" and "convince" have a relative future in the complement:

(18) R Dogovorilis' ${ }_{\text {PAST-PF }}$ o vstreče čerez nedelju, Sergej obeščal ${ }_{\text {PAST-IMPF, }}$,

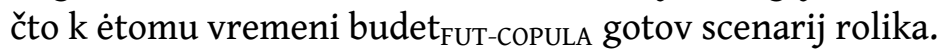
(Viktor Pelevin, "Pokolenie P")

E They agreed to meet again in a week's time; Sergei promised the scenario for the video would be ready by then.

$\mathrm{N}$ De avtalte $\mathrm{PAST}_{\mathrm{PA}}$ a møtes $\mathrm{INF}_{\mathrm{INF}}$ om en uke. Sergej lovte $\mathrm{PAST}_{\mathrm{PAT}}$ at scenarioet til videoklippet skulle PAST-MODAL være $_{\text {INF }}$ ferdig til den tid.

(19) R Djadja poobeščal ${ }_{\text {PAST-PF }}$ emu, čto v samoe bližajšee vremja ego posadjat $_{\text {FUT-PF }} \mathrm{v}$ tjur'mu. (Ljudmila Ulitskaja, "Medeja i ee deti")

E His uncle assured him that he would land himself in jail in the very near future

$\mathrm{N}$ Onkelen lovte $\mathrm{PAST}_{\mathrm{P}}$ ham at han nokså snart skulle $\mathrm{PAST}_{\mathrm{PAOAL}}$ sørge $_{\text {INF }}$ for å få

With a non-finite complement, as the Russian (20R), the relative future is covert:

(20) N Hun overbeviste $\mathrm{PAST}_{\mathrm{P}}$ Goupils om at de burde $\mathrm{P}_{\mathrm{PAST}-\mathrm{MODAL}}$ sette $_{\text {INF }}$ ned rentene. (Nikolaj Frobenius, "Latours katalog")

[10] Note that our treatment of the synthetic Russian "perfective future" is different from our analysis of the periphrastic future in English and Russian inasmuch as auxiliaries like "will" and "budet" are verbal quantifiers with a feature uN, hence subject to the sот parameter. The English auxiliary "have" is a verbal quantifier as well. 
E She persuaded Goupils that they should lower their interest rates.

$G$ Sie überredete $e_{\text {PAST }}$ Goupils, die Zinsen herabzusetzen $n_{\text {INF. }}$.

F Elle persuada PAST-PF $_{\text {Goupil qu'ils devaient }}$ PAST-IMPF-MODAL abaisser $_{\text {INF }}$ leurs taux d'intérêt.

R Ona ubedila $a_{\text {PAST-PF }}$ Gupilja snizit' ${ }_{\text {INF }}$ procenty.

Forward shifted interpretations under factives are always encoded with "future under past" in Russian:

(21) N Jacob skjønte PAST $_{\text {at hun kom }}$ aAST-MODAL til å dra INF alene om han ikke føyde ${ }_{\text {PAST }}$ henne. (Herbjørg Wassmo, "Dinas bok")

E Jacob realized she would go alone if he did not accompany her.

$G$ Jacob begriff $f_{\text {PAST }}$, daß sie allein hinfahren ${ }_{\text {INF }}$ würde $_{\text {PAST-SUBJ-MODAL, }}$, wenn er sich nicht fügte PAST $_{\text {. }}$

F Jacob comprit PAST-PF $_{\text {qu'elle était }}$ PAST-IMPF $_{\text {capable d'y aller }}$ INF seule

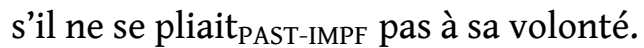

$\mathrm{R}$ Iakov ponjal $\mathrm{PAST}-\mathrm{PF}$, čto ona poedet $\mathrm{FUT}_{\mathrm{FUF}}$ odna, esli on ej ne ustupit $_{\mathrm{FUT}-\mathrm{PF}}$.

\section{[2.3] Backward shifted interpretation under past attitudes}

In Russian, "past under past" is expected to have the shifted reading, meaning that the time of the complement precedes the matrix. In sот languages, where "past under past" by default produces a simultaneous interpretation, the backward shifted interpretation is normally conveyed through tense transposition using a past perfect in the complement. A typical example is given in (22) with a feature analysis as sketched in Figure 5.

(22) $\mathrm{R}$ Ona [...] sprosila $a_{\text {PAST-PF }}$ spal $_{\text {PAST-IMPF }}$ li on.

(Lev Tolstoj, "Anna Karenina”)

E She [...] asked him if he had slept.

$\mathrm{N}$ Hun $[\ldots]$ spurte $_{\text {PAST }}$ om han hadde PAST-AUX $_{\text {sovet }}$ PART.

PAST She asked him $\varnothing$-tense if he had slept (English)

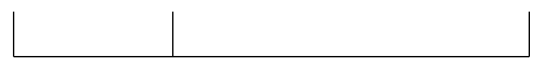

NON-LOCAL AGREEMENT

PAST Ona sprosila $\varnothing$-tense PAST spal li on (Russian)
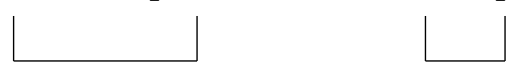

LOCAL AGREEMENT

FIGURE 5: Backward shifted interpretation under past attitude 
The English auxiliary "had" is a verbal quantifier. ${ }^{11}$ It has the same semantics as the PAST operator. In our example, its morphology is checked by the higher PAST associated with the matrix. The semantic precedence relation in the sOT languages thus comes from the perfect "have" operator in (22E) and (22N).

In non-sot languages like Russian, the past tense morphology in the complement points to a local semantic past operator. Recall from our introductory remarks above that tenses are shifters, i.e., quantifiers based on temporal relations, and that the highest tense under the attitude is a zero tense, bound by lambda abstraction. Thus, when we have a semantic PAST under a verbal quantifier as in $(22 \mathrm{R})$, it is not the "past variable" that is bound, but the "perspective variable" to which this variable is related.

The same patterns as in (22) occur frequently in the parallel corpora. Example (23) below is similar, except for an aspectual difference in Russian: In (23R), the matrix is imperfective and the complement is perfective, while in (22R) the matrix was perfective and the complement imperfective. In the examples under discussion, this aspectual distinction does not seem to make any difference for the temporal ordering of the events - in both cases the complement event/state precedes the matrix event/state, hence a shifted reading (but see section [4.1] below on the role of aspect in Russian non-sot configurations).

(23) N Kokka mente $e_{\mathrm{PAST}}$ at lensmannen hadde $\mathrm{PAST}_{\mathrm{AUXX}}$ nok ikke spart PART $_{\mathrm{PA}}$ pa kruttet. (Herbjørg Wassmo, "Dinas bok")

E The cook remarked that the sheriff obviously had not spared gunpowder when he fired his cannon.

$G$ Die Köchin meinte ${ }_{\text {PAST }}$, daß der Lehnsmann wohl nicht mit dem Schießpulver gespart PART $_{\text {habe }}$ hRES-SUBJ-AUX, als er feuerte PAST $_{\text {. }}$.

$\mathrm{R} \quad$ Kucharka sčitala $\mathrm{PAST}_{\mathrm{PMPF}}$, čto lensman ne požalel $\mathrm{l}_{\text {PAST-PF }}$ porochu.

Here are some examples with factive attitude verbs and backward shift:

(24) N Men de visste PAST $_{\text {a }}$ at han endelig hadde PAST-AUX $_{\text {tatt }}$ PAST-PART lutningseksamen. (Herbjørg Wassmo, "Dinas bok")

E But they knew he had taken his final examinations at last.

$G \quad$ Aber sie wußten ${ }_{P A S T}$, daß er endlich sein Abschlußexamen gemacht $_{\text {PART }}$ hatte PAST-AUX.

F Mais on savait $t_{\text {PAST-IMPF }}$ qu'il avait $t_{\text {PAST-AUX }}$ enfin passé PART $_{\text {PAs }}$ ses derniers examens.

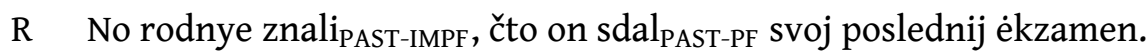

(25) N Han visste PAST $_{\text {at han hadde }}$ aAST-AUX vært $_{\text {PART }}$ den betydeligste i red-

[11] The present form "has" has a special semantics as it may express the "extended now"; cf. (Dowty 1979, chap. 7). 
ningsarbeidet. (Herbjørg Wassmo, "Dinas bok")

E He knew he had done more than anyone else to save the barn.

$G \quad$ Er wußte $_{\text {PAST }}$, daß er bei den Rettungsarbeiten der Wichtigste gewesen PART $_{\text {War }}$ PAST-AUX.

F Il savait $t_{\text {PAST-IMPF }}$ qu'il avait PAST-IMPF-AUX $_{\text {eu }}$ eu $_{\text {PART }}$ le rôle le plus important dans la lutte contre le feu.

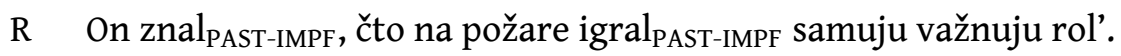

While "past under past" typically has a simultaneous interpretation in soт languages, the context can also license a shifted interpretation similar to the Russian "past under past" construction. In fact, it is well-known from the sот-literature that "past under past" leads to a shifted interpretation for Germanic and Romance languages when the embedded sentence is perfective (or eventive). ${ }^{12}$ This is illustrated in the English translation in (26E) with a simple "past under past" - in contrast to the past perfect found in the Norwegian translation (26N).

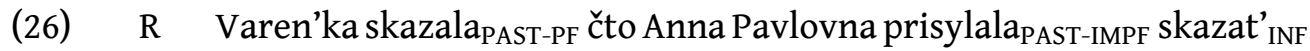
čto vy ne poedete ${ }_{\text {FUT-PF }}$ (Lev Tolstoj, "Anna Karenina”)

E Varenka said that Anna Pavlovna sent word you were not going.

$\mathrm{N}$ Varenka sa $\mathrm{PAST}_{\mathrm{PA}}$ at Anna Pavlovna hadde $\mathrm{PAST-AUX}$ sendt $\mathrm{PART}_{\text {PAd }}$ bud at ikke ble PAST $_{\text {noe }}$ av turen.

The fact that the translators in (26) have chosen different forms is "accidental" - both English and Norwegian have both constructions. Thus, a simple past in English and Norwegian can have the same meaning as a past perfect, but it need not, cf. Figure 6.

... $\varnothing$-tense A.P. sent feature transmission from higher tense

$\left.\begin{array}{l}\text {... } \varnothing \text {-tense A.P. PAST sent } \\ \varnothing \text {-tense A.P. had sent }\end{array}\right\}$ synonymous - backward shifted interpretation

FIGURE 6: Embedded simple past vs. past perfect

Although (26E) and $(26 \mathrm{~N})$ are truth-conditionally indistinguishable, only the latter relies on the sот parameter for the licensing of the verb form (the auxiliary "hadde" with past morphology, and not "har" with present morphology) embedded under the highest verbum dicendi. The past tense morphology on the auxiliary "hadde" is thus semantically void, the anteriority being conveyed by the lexical semantics of the verbal quantifier "ha" - "have".

[12] This forced backward shifted interpretation has a certain parallel in the well-known fact for all speakers of Russian that the combination of present tense + perfective aspect requires a shifted future interpretation due to the incompatibility of the perfective complete event configuration with a punctual present topic time. 
For the second embedding under "sent word", both (26E) and (26N) require the insertion at LF of a silent FUTURE. The feature transmission for the English sentence in (26E) is shown in Figure 7.

PAST V said that $\varnothing$-tense A.P. PAST sent word $\varnothing$-tense you were FUT not going

LOCAL AGREEMENT

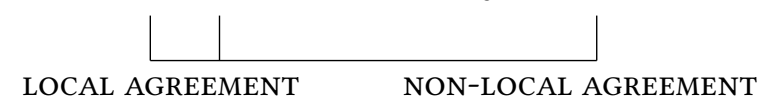

FIGURE 7: Local and non-local agreement in English

Thus, the two embeddings in (26E) demonstrate both local ( $\mathrm{P}$ - "said" and $\mathrm{P}-$ "sent word") and non-local ("were") agreement. ${ }^{13}$

The Russian original in (26R) also deserves special mention. We have two verba dicendi - the first embeds a relative past and the second a relative future. As expected for a non-sот language, the relative future is expressed with a perfective future. On the other hand, surprisingly, the relative past is expressed with an IMPERFECTIVE PAST, "prisylala PAST-IMPF" ("sent"), instead of the perfective aspect. This peculiar use of the imperfective with a "perfective" complete event interpretation - the so-called konstatacija fakta ("the factual imperfective") - is quite common in Russian and was treated extensively in (Grønn 2003), see also (Altshuler this volume).

\section{[2.4] Simultaneous interpretation under future attitudes}

We ignore data with a present tense matrix since the dependent/independent distinction is typically blurred in this environment. On the other hand, configurations with a future matrix attitude verb are expected to comply with the soT parameter. We observe "present under future" both in English and Russian:

(27) E Hanging around like this, people will think you're up to something. (Joanne K. Rowling, "Harry Potter and the Sorcerer's Stone")

$\mathrm{R}$ Esli vy budete ${ }_{\text {PRES-IMPF-AUX }}$ raschaživat' ${ }_{\text {IMPF-INF }} s$ tainstvennym vidom, to vse podumajut $t_{\mathrm{FUT}-\mathrm{PF}}$, čto vy opjat' čto-to zatevaete $\mathrm{PRES}_{\mathrm{IMPF}}$.

Despite the apparent similarities between the temporal surface structures in (27E) and (27R), the soт parameter forces different LFs for the two languages. This is depicted in Figure 8 on the next page. In English, both "will" and "think" are verbal quantifiers which transmit the feature $\mathrm{N}$ from the deictic utterance situ-

[13] We will, however, see that our implementation of feature transmission enables us to maintain obligatory feature transmission in оот-languages. The feature uP originating in the highest matrix PAST is transmitted to the TEMPORAL CENTER of an embedded semantic PAST. Here its voyage ends. The embedded PAST associated with "sent word" transmitts its own feature uP to the embedded verb "were". In the case of temporal agreement, as between "sent word" and "were", the feature is transmitted to the variable created by a zero tense (TPRO) and further transmitted to the verb. 
N people will think $\varnothing$-tense you're up to something (English)

FUT vse podumajut čto $\varnothing$-tense PRES vy opjat' čto-to zatevaete (Russian)
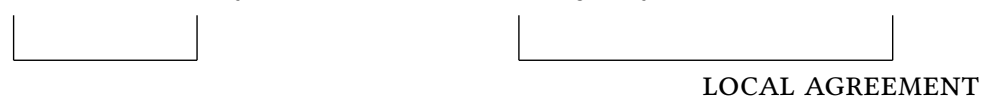

FIGURE 8: Simultaneous interpretation under future attitude

ation. In Russian, the checking relation is broken by the verbal quantifier "dumat'/think", hence a relative PRESENT must be inserted in the complement to license the present tense morphology of "zatevaete - be up to something".

Many examples of English and Russian in the parallel corpora display a similar pattern as in (27), i.e., "present under future". However, the context typically suggests an independent (deictic) interpretation of the complement, hence the data are not directly related to the sот parameter. An example of independent complement tense is given in (28). ${ }^{14}$

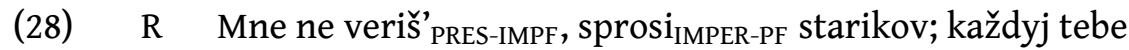
skažet $_{\text {FUT-PF, }}$ čto ryba teper' sovsem ne ta, čto byla PAST-IMPF. . (Anton Čechov, "Svirel”)

E If you don't believe me ask the old people; every old man will tell you that the fish are not at all what they used to be.

\section{[2.5] Forward shifted interpretation under future attitudes}

With a forward shifted interpretation under a future matrix we expect to find an additional FUTURE operator in the complement. The pattern is illustrated in two examples below:

(29) E 'Well,' said the gipsy, 'I'll tell you what I will do.'

(Kenneth Grahame,"The Wind in the Willows")

R Ladno, skazal PAST-PF $_{\text {cygan, ja tebe skažu }}$ FUT-PF, čto ja sdelaju FUT-PF. $_{\text {. }}$.

(30) E I am going to reply to Mark Darcy's invitation and say quite clearly and firmly that I will be unable to attend.

(Helen Fielding, "Bridget Jones's Diary")

$\mathrm{R}$ Sejčas otveču ${ }_{\mathrm{FUT}}$-PF na priglašenie Marka Darsi i vežlivo, no tverdo

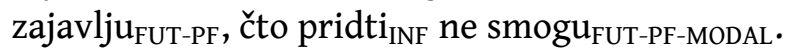

[14] The present tense complement in the English translation ("the fish are not ...") of this example corresponds to a present tense zero copula in Russian ("ryba teper' sovsem ne ta"). 


\section{[2.6] Backward shifted interpretation under future attitudes}

The backward shifted interpretation is highly frequent in the parallel corpora. As expected, Russian expresses the relative past with past tense morphology: "past under future". In sot languages of the Germanic type we typically find "present_perfect under future" in this environment (with feature transmission through the infinitive complement of "will"). Compare the constructions in (31) and their temporal feature checking in Figure 9.

(31) E "When I have caught forty fish," said he, "then I will tell people that I have caught fifty, and so on."

(Jerome K. Jerome, "Three Men in a Boat")

$\mathrm{R}$ “Kogda ja pojmaju $\mathrm{FUT}_{\mathrm{FUT}}$ sorok štuk”, govoril PAST-IMPF $_{\text {on, “ja }}$ budu PRES-IMPF-AUX vsem rasskazyvat $_{\text {IMPF-INF, }}$ čto pojmal ${ }_{\text {PAST-PF }}$ pjat'desjat, i tak dalee."

N I will tell people that $\varnothing$-tense I have caught fifty (English)

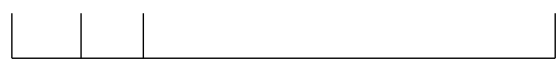

NON-LOCAL AGREEMENT

$\mathrm{N}$ ja budu vsem rasskazyvat' čto $\varnothing$-tense PAST pojmal 50 (Russian)
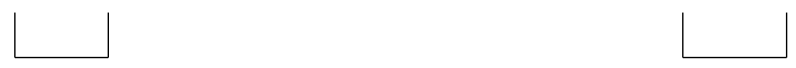

LOCAL AGREEMENT

FIGURE 9: Backward shifted interpretation under future attitude

The "present_perfect under future" competes with the "past under future" in sот languages, as witnessed by (32N) vs. (32E):

(32) R Ja skažu $u_{\mathrm{FUT}-\mathrm{PF}}$ im, čto prosto na nočleg zašel $\mathrm{PAST}_{\mathrm{PAF}}$.

(Ljudmila Ulitskaya, "Medeja i ee deti")

E I'll tell them I just came in to find a room for the night, no more than that.

$\mathrm{N}$ Jeg skal PRES-AUX $_{\text {INF }}$ til de typene at jeg ganske enkelt har PRES-AUX $_{\text {I }}$ tinget PART $_{\text {meg nattelosji her. }}$

The analysis of the "present_perfect under future" in (32N) is straightforward the present tense auxiliary in the complement gets its morphology from the deictic $\mathrm{N}$ in the matrix through the verbal quantifiers "skal - will" and "si - say". The English "past under future" shows that we must allow for the insertion of a relative PAST in the complement also in sot languages, similar to what we observed with a backward shifted "past under past" in section [2.3] (importantly, a relative PRES like in Russian cannot be inserted in the same environment in English). 
Constructions like the "past under future" or "present_perfect under future" are often ambiguous between a dependent and independent (deictic) interpretation of the complement (Abusch 1994a). A dependent interpretation amounts to the precedence relation "complement tense $<$ matrix tense". However, the context may pragmatically license a stronger interpretation, viz. the precedence relation "complement tense $<$ utterance time".

\section{[3] ANALYSIS}

The data in section [2] convincingly show that:

- English is a clear sот language - simultaneity under attitudes is expressed by temporal agreement.

- Russian is a non-sот language - simultaneity under attitudes is expressed by the present.

We will now present the details of a formal analysis. We also refer the reader to (von Stechow 2009) for an introduction to tense semantics and feature theory.

\section{[3.1] Temporal structure of simple sentences}

Our LFs are expressions of an intensional $\lambda$-language, which is based on the types $\mathrm{e}$ (individuals), i (times), $\mathrm{v}$ (events), $\mathrm{t}$ (truth-values), s (world histories). "Intensional" means that expressions of type a express meanings of type (sa), i.e., "aintensions". For details see section [3.3] below.

a. John called.

b. Mary is happy.

(34) Tenses

a. Present, type i: $\llbracket \mathrm{N} \rrbracket=\lambda w \cdot s^{*}$

b. Past, type i(it,t): $\llbracket \mathbf{p} \rrbracket=\lambda w \lambda t \lambda Q_{\text {it }} \cdot\left(\exists t_{1}\right)\left[t_{1}<t \& Q\left(t_{1}\right)\right]$ (Heim 1997)

$s^{*}$ is the speech time. Thus the semantic present simply denotes the speech time. $\mathrm{P}$ is an indefinite relative past. ${ }^{15}$ The argument of $\mathrm{P}$ is always $\mathrm{N}$ in matrix clauses. In subordinate clauses, $\mathrm{P}$ can have a time variable $t$ as argument that is bound by a higher tense or locally bound by a $\lambda$-operator.
a. $\llbracket \mathrm{John}_{\mathbf{e}} \rrbracket=\lambda w$.John
b. $\quad\left[\right.$ called $_{\mathrm{i}(\mathrm{et})} \rrbracket=\lambda w \lambda t \lambda x . x$ calls in $w$ at $t$.
c. $\quad\left[\right.$ happy $_{\mathrm{i}(\mathrm{et})} \rrbracket=\lambda w \lambda t \lambda x . x$ is happy in $w$ at $t$.

feature: uP no tense feature

[15] For the Partee Problem, see (von Stechow 2009). 
The time argument is the first by convention. Like "happy", "called" has a tenseless semantics! The morphology of the latter is checked by a semantic tense.

At deep structure (DS), the time argument is filled by the semantically empty pronoun PRO, which is moved for type reasons at LF (cf. the PRO-theory of (Heim \& Kratzer 1998, 226-228)). PRO-movement is an essential ingredient for the construction of binding chains for feature transmission.

(36) Derivation of (33a)

DS: [T⿻ [T P N] [vp John [called PRO]]]

PRO movement (with subsequent PRO deletion)

LF: $\mathrm{N} \lambda_{0}\left[{ }_{\mathrm{TP}}\left[\mathrm{T}_{\mathrm{P}} t_{0}\right]\right.$ PRO $\lambda_{1}\left[\mathrm{VP}\right.$ John [called $\left.\left.\left.t_{1}\right]\right]\right]$

$=\lambda w \cdot\left(\exists t<s^{*}\right)$ John calls in $w$ at $t$

(37) The temporal auxiliary вE:

$\llbracket \mathrm{Is} \rrbracket=\lambda w \lambda t \lambda P_{\mathrm{it}} \cdot P(t)$

type i(it,t)

feature: uN

Present tense copulas have a completely trivial semantics, and therefore they do not count as verbal quantifiers when it comes to feature transmission. This also holds for the Russian covert present tense copula.

$$
\begin{aligned}
& \text { Derivation of (33b) } \\
& \text { DS: [TP N [VP [v is PRO] [AP Mary happy PRO]]] } \\
& \text { PRO movement (with subsequent PRO deletion) } \\
& \text { LF: [TP N PRO } \left.\left.\left.\lambda_{1} \text { [VP [v is } t_{1} \text { ] PRO } \lambda_{2} \text { [AP Mary happy } t_{2}\right]\right]\right] \\
& =\lambda w \text {. Mary is happy in } w \text { at } s^{*}
\end{aligned}
$$

The perfect temporal auxiliary HAVE is a verbal quantifier, which has the same meaning as the semantic past. But as a verb it has its own morphology, which has to be licensed by a semantic tense. (The EXTENDED NOw meaning for HAVEpres is ignored here).

$$
\begin{aligned}
& \text { HAS/HAD: type i(it,t) } \quad \text { features: HAS uN; HAD uP } \\
& \lambda w \lambda t \lambda P_{\text {it }} .\left(\exists t_{1}\right)\left[t_{1}<t \& P\left(t_{1}\right)\right] \quad
\end{aligned}
$$

(40) John had called.

$[$ it,t $\mathrm{P} \mathrm{N}]\left[\lambda_{1}\left[\left[\right.\right.\right.$ had $\left.t_{1}\right]\left[\lambda_{2}\left[\mathrm{John}\left[\right.\right.\right.$ called $\left.\left.\left.\left.\left.t_{2}\right]\right]\right]\right]\right]$

$=\lambda w \cdot\left(\exists t_{1}\right)\left[t_{1}<s^{*} \&\left(\exists t_{2}<t_{1}\right)\left[\right.\right.$ John calls in $w$ at $\left.\left.t_{2}\right]\right]$

The future auxiliary WILL is the mirror image of HAVE:

$$
\begin{aligned}
& \text { wILL: type i(it,t) } \\
& \lambda w \lambda t \lambda P_{\text {it }} .\left(\exists t_{1}\right)\left[t_{1}>t \& P\left(t_{1}\right)\right]
\end{aligned}
$$

feature $\mathrm{uN}$

The temporal auxiliary would has the same meaning but the feature uP. 


$$
\begin{aligned}
& \text { John will call. } \\
& \mathrm{N}\left[\lambda_{1}\left[\left[\text { will } t_{1}\right]\left[\lambda_{2}\left[\mathrm{John}\left[\text { call } t_{2}\right]\right]\right]\right]\right] \\
& =\lambda w \cdot(\exists t)\left[t>s^{*} \& \mathrm{John} \text { calls at } t\right]
\end{aligned}
$$

Russian BUDET ("will") has the same semantics as English wiLl, and it has the feature uN. In addition it SUBCATEGORISES for an imperfective verb, hence the embedded infinitive is always in the imperfective. ${ }^{16}$ This subcategorisation merely serves the purpose to implement aspect selection and is purely syntactic, cf. the traditional notion of "status government". The phenomenon is similar to the requirement (in English) that modals like "must" and "can" subcategorise for an infinitive, while "have" subcategorises for a past participle. This kind of subcategorisation can be captured by special subcategorisation features.

\section{[3.2] Feature Theory: Temporal agreement}

Following Chomsky (1995), Zeijlstra (2004), among others, we assume the following theory of features: There are two sorts of features, interpretable ones [iF] and uninterpretable ones [uF]. Interpretable features check uninterpretable features.

Finite verb forms have uninterpretable temporal features. Present forms of a verb have the feature [uN] "uninterpretable Present/Now". The semantic Present $\mathrm{N}$ has the feature [iN] "interpretable Present/Now". Past forms of a verb have the feature [uP] "uninterpretable Past", while the semantic past tense $\mathrm{P}$ has the feature [iP]. Below are some verb forms in English with spell out:

(43) Present: call/calls

Past: called

Past Participle: called

Infinitive: call

(no inherent temporal feature)

Meaning of all these: $\lambda w \lambda t \lambda x . x$ calls in $w$ at time $t$

Our principles of feature transmission under semantic binding follow (Heim 1994b) and (Heim 2005): A semantic tense $\mathrm{P}$ or $\mathrm{N}$ transmits a feature [uP]/[uN] to the time variable it binds. If the variable is an argument of a tensed verb form, the feature has to agree with the tense feature of the verb, i.e., with the verbal morphology.

We furthermore assume the conventions for semantic binding outlined in (Heim \& Kratzer 1998). In particular, a phrase or operator $\alpha$ may bind a variable via a $\lambda$-operator. In addition to quantifier raising $(\mathrm{QR}), \lambda$-abstracts are created by PRO- and WH-movement. As said above, our theory makes crucial use of PROmovement, as can be seen by comparing the deep structure (DS) and logical form (LF) of a toy sentence in Figures 10 and 11 on the following page.

First, a note to the percolation of tense features. Features percolate along the

[16] Imperfective verbs must be licensed by a semantic imperfective operator, but this operator is not subcategorised by "budet" directly. 


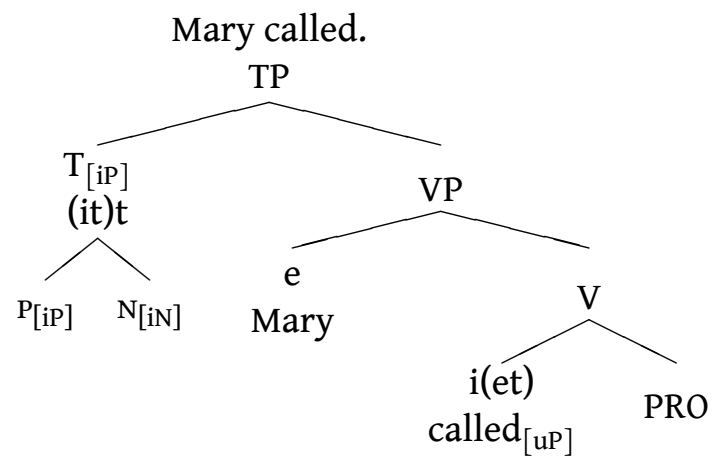

FIGURE 10: DS (not interpretable)

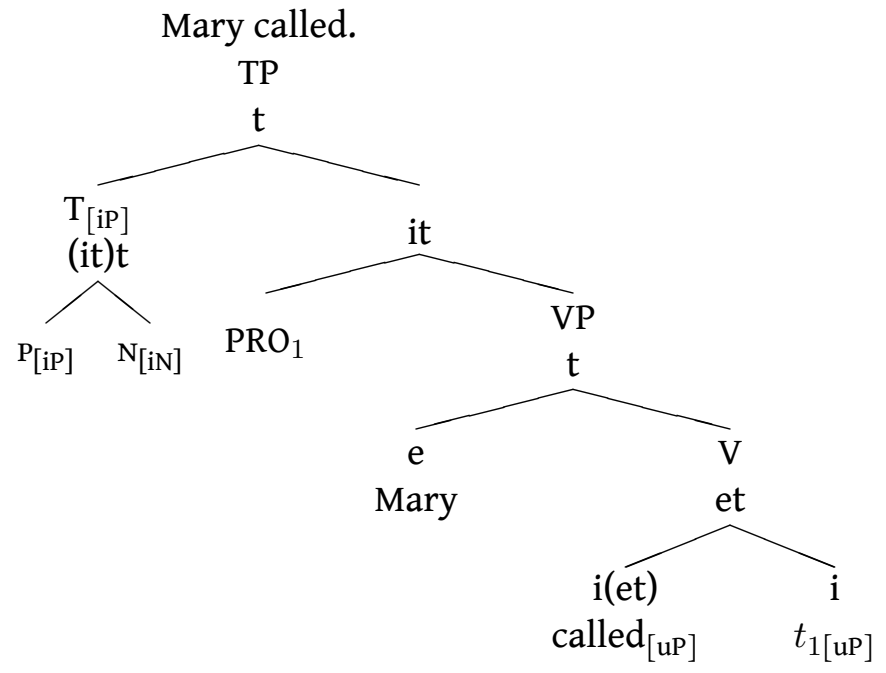

FIGURE 11: LF (interpretable)

head line. The feature of a temporal variable either agrees with the inherent feature of the head (as in finite verbs) or it is transmitted to the head (and percolates to the phrase). Since the semantic past is the head of the semantic tense [P N], the feature [iP] percolates to the phrase [P N].

The LF in Figure 11 is created by PRO-movement: PRO is semantically void and has to be moved for type reasons. Assuming Heim \& Kratzer's QR conventions, PRO leaves the variable $t_{1}$ in situ. The movement index of PRO is interpreted as the $\lambda$-operator. Given that PRO is semantically empty, it is deleted at LF by Chomsky's principle of Full Interpretation (our trees do not represent the deletion). Thus $\mathrm{PRO}_{i}$ can be read as $\lambda_{i}$. Note that the transmission mechanism sends the feature iP of the semantic past $\mathrm{P}$ to the bound variable $t_{1}$. Here the feature locally agrees with the inherent temporal feature uP of called. Non-finite forms 
have a temporal feature on their variable as well, but since they lack inherent temporal morphology, we do not need the features for licensing the morphology. We may need them instead for feature transmission to further embedded tenses.

\section{[3.3] Intensions}

We introduce an intensional $\lambda$-language with the following recursive definition of the interpretation function based on a function $F$ that interprets the lexicon and a variable assignment $g, \llbracket \cdot \rrbracket_{F, g}$ :

(i) Let $\alpha$ be a lexical entry of type a. Then $\llbracket \alpha \rrbracket^{M, g}=F(\alpha)$.

(ii) Let $x$ be a variable of type a. Then $\llbracket x \rrbracket^{M, g}=\lambda w \cdot g(x), g(x) \in D_{\mathrm{a}}$.

(iii) FA: Let $\alpha$ have type $b$ and daughters $\beta$ of type $a b$ and $\gamma$ of type a. $\llbracket \alpha \rrbracket^{M, g}=\lambda w \cdot \llbracket \beta \rrbracket^{M, g}(w)\left(\llbracket \gamma \rrbracket^{M, g}(w)\right)$ (functional application)

(iv) IFA: Let $\alpha$ have type $b$ and daughters $\beta$ of type (sa)b and $\gamma$ of type a. $\llbracket \alpha \rrbracket^{M, g}=\lambda w \cdot \llbracket \beta \rrbracket^{M, g}(w)\left(\llbracket \gamma \rrbracket^{M, g}\right)$ (intensional functional application)

(v) PM: Let $\alpha$ have the daughters $\beta$ and $\gamma$, all of type at, and let $x$ by of type a. $\llbracket \alpha \rrbracket^{M, g}=\lambda w \lambda x \cdot \llbracket \beta \rrbracket^{M, g}(w)(x) \& \llbracket \gamma \rrbracket^{M, g}(w)(x)$ (predicate modification)

(vi) ABSTRACTION: Let $x$ be a variable of type a and $\alpha$ an expression of type $b$. $\llbracket \lambda x \alpha \rrbracket^{M, g}=\lambda w \lambda u \in D_{\mathrm{a}} \cdot \llbracket \alpha \rrbracket^{M, g[x / u]}(w)$

\section{[3.4] Tense under attitudes}

Attitudes are verbal quantifiers and quantify over worlds and times (and individuals, neglected here). We repeat the core semantics here in the style of (Lewis 1979):

【believe $\left(\right.$ s(it))(i,et) $\rrbracket=\lambda w \lambda P_{\text {s(it) }} \lambda t \lambda y \cdot\left(\forall w_{1}\right)\left(\forall t_{1}\right)\left[\left(w_{1}, t_{1}\right)\right.$ is compatible with everything $y$ believes of $(w, t)$ in $w$ at time $\left.t \rightarrow P\left(w_{1}\right)\left(t_{1}\right)\right]$

Hence complements must be properties of time, type s(it). The properties are generated by assuming a temporal PRO (or TPRO) as the highest semantic tense ("zero tense"). PRO has to be moved for type reasons and thus creates a temporal abstract. This follows from the logical type of the attitude verb. Details aside, the analysis follows Kratzer (1998).

Verbs of speech ("say", "tell") and verbs of thought ("think", "believe") follow this scheme. The same also holds for factive verbs ("know", "understand"), which have an additional factive presupposition that the complement is true. We will say more about their semantics in section [4.3]. Control verbs like "promise" or "convince" behave similarly with the additional proviso that we find a covert relative future in non-finite complements: 
(45) a. John promised Jane he would vote for Obama.

b. John promised Jane to vote for Obama.

c. John convinced Jane to vote for Obama.

The sentence in (45a) has an explicit relative future ("would") in the complement. Since (45b) means the same, we must assume a covert FUTURE in the complement of the latter. (45c) is analysed analogously to (45b), i.e., with a covert FUTURE as well. Control verbs are rarely discussed in the sot literature, so we give the relevant lexical entries here for the interested reader:
a. promise with finite complement: ${ }^{17}$
$\lambda w \lambda P_{\mathrm{si}(\mathrm{et}))} \lambda x \lambda y \lambda t .\left(\forall w_{1}\right)\left[w_{1} \in \operatorname{Acc}(y, w, t) \rightarrow P(y)\left(w_{1}\right)(t)\right]$
b. convince (object control): ${ }^{18}$
$\lambda w \lambda P_{\mathrm{s}(\mathrm{i}(\mathrm{et}))} \lambda x \lambda y \lambda t .\left(\forall w_{1}\right)\left[w_{1} \in \operatorname{Acc}(x, w, t) \rightarrow P(x)\left(w_{1}\right)(t)\right]$

These are the LFs for the sentences in (45):
a. $\quad \mathrm{N} \lambda_{1} \mathrm{P}\left(t_{1}\right) \lambda_{2}$ John promised $\left(t_{2}\right)$ Jane $\lambda_{4} \operatorname{HE} \lambda_{6}$ would $\left(t_{4}\right) \lambda_{5} x_{6} \operatorname{vote}\left(t_{5}\right)$ for Obama.
b. $\quad \mathrm{N} \lambda_{1} \mathrm{P}\left(t_{1}\right) \lambda_{2}$ John promised $\left(t_{2}\right)$ Jane PRO $\lambda_{4}$ PRO $\lambda_{6} \mathrm{FUT}\left(t_{4}\right) \lambda_{5} x_{6}$ to $\operatorname{vote}\left(t_{5}\right)$ for Obama.
c. $\quad \mathrm{N} \lambda_{1} \mathrm{P}\left(t_{1}\right) \lambda_{2}$ John convinced $\left(t_{2}\right)$ Jane PRO $\lambda_{4} \mathrm{PRO} \lambda_{6} \mathrm{FUT}\left(t_{4}\right) \lambda_{5} x_{6}$ to $\operatorname{vote}\left(t_{5}\right)$ for Obama.

The HE in (47a) is a de se pronoun. Like PRO it is semantically void and has to be moved for type reasons. ${ }^{19}$ This gives a parallel analysis for finite and non-finite complements, a desideratum pronounced in (Katz 2002).

\section{English attitudes}

Thus, attitude verbs are verbal quantifiers. The sот parameter says that these verbs in English transmit their temporal features under binding to the temporal variable in the clausal complement.

Here are the relevant LFs:

At 5 o'clock Mary thought it was 6 o'clock. ${ }^{20}$

The temporal variable of the subordinate "was" inherits its feature from the

[17] The formula ignores the fact that the subject $(y)$ addresses the indirect object $(x)$.

[18] The causative component of convince is ignored here, hence the rule does not make explicit that the subject $(y)$ excerces pressure on the object $(x)$.

[19] The de re case with mistaken identity has to be analysed differently, say, with the method of structured propositions; see e.g. (von Stechow \& Cresswell 1982).

[20] Identity $\left(t_{1}=6\right.$ o'clock) is transcendental, i.e., not dependent on worlds. Therefore the abstraction over worlds $\left(\lambda w_{1}\right)$ applies vacuously in Figure 12 on the next page. 
$\mathrm{N} \lambda_{0} \mathrm{P}\left(t_{0}\right) \lambda_{1} t_{1}$ at 5 Mary thought $\left(t_{1}\right) \mathrm{PRO} \lambda_{4} t_{4} \lambda_{2}$ was $\left(t_{2}\right) \lambda_{3} t_{3}$ at 6

iP uP uP uP

$=\lambda w \cdot\left(\exists t<s^{*}\right)\left[t=5\right.$ o'clock \& Mary thinks in $w$ at $t\left[\lambda w_{1} \lambda t_{1} \cdot t_{1}=6\right.$ o'clock $\left.]\right]$

FIGURE 12: "Past under past" in English (simultaneous)

matrix P via feature transmission through "thought", cf. Figure 12. The temporal adverb at " 5 o'clock" means $\lambda w \lambda t . t$ is 5 o'clock. It is composed with the VP by Predicate Modification; for details, see section [3.3] above.

Next, in Figure 13, we analyse the shifted reading.

Mary thought Bill left.

$\mathrm{N} \lambda_{0} \mathrm{P}\left(t_{0}\right) \lambda_{1}$ Mary thought $\left(t_{1}\right) \mathrm{PRO} \lambda_{2} \mathrm{P}\left(t_{2}\right) \lambda_{3} \operatorname{Bill}$ left $\left(t_{3}\right)$

iP $\quad$ UP iP uP

$=\lambda w \cdot\left(\exists t_{1}<s^{*}\right)$ Mary thinks in $w$ at $t_{1}\left[\lambda w_{1} \lambda t_{2} \cdot\left(\exists t_{3}<t_{2}\right)\right.$ Bill leaves in $w_{1}$ at $\left.t_{3}\right]$ FIGURE 13: "Past under past" in English (anterior)

The complement contains its own relative past that checks the uP of the past verb form "left". Hence we get the shifted interpretation. ${ }^{21}$

\section{Russian attitudes}

The Russian verbal quantifier BUDET and verbs of attitudes do not transmit temporal features. This is what the sот parameter says for non-soт languages.

The relative PRESENT plays an important role in Russian complements:

$$
\begin{aligned}
& \text { Russian Present } \\
& \llbracket \text { PRES }_{\text {Rus } \rrbracket}=\lambda w \lambda t \lambda P_{\text {it }} . P(t)
\end{aligned}
$$

feature iN

Semantically PRES Rus is identity, i.e., void. The trivial operator merely serves the purpose to assign the feature $\mathrm{uN}$ to the temporal variable it binds. This is the PRESENT analysis for non-sOT languages of Ogihara (1996). ${ }^{22}$

As it stands, PRES Rus has the same semantics as the copula (e.g. the English is or the Russian $\varnothing$ ). Importantly, however, the role of PRESRus in the feature system of Russian is different from that of the silent present tense copula. The latter does not interact with transmission of temporal features since it is certainly not a genuine verbal quantifier; despite its logical type the present copula is intuitively not a TIME SHIFTER. This point is also in line with the observation made elsewhere in this paper that invisible operators always transmit features. Accordingly, in

[21] A remark to the notation in Figures 12 and 13: "Mary thinks in $w$ at $t\left[\lambda w_{1} \lambda t_{1} \cdot P\left(w_{1}\right)\left(t_{1}\right)\right]$ " is, of course, equivalent with the notation used elsewhere in this paper: $\left(\forall w_{1}, t_{1}\right) \in \operatorname{Dox}_{\text {Mary }}(w, t) \rightarrow P\left(w_{1}\right)\left(t_{1}\right)$.

[22] Ogihara's PRES Jap is $\lambda w \lambda t \lambda P_{\text {it }} .\left(\exists t_{1}\right)\left[t_{1}=t \& P\left(t_{1}\right)\right]$. This is equivalent to our formulation. 
our examples, copulas do not block feature transmission and feature assignment by copulas will be ignored.

English-type languages seem to lack a relative PRESENT of the Russian kind, otherwise we cannot explain the impossibility in English of "present under past" with a simultaneous, dependent interpretation (cf. example (1) above):

He said that he lives outside Moscow.

*simultaneous, dependent interpretation. (only "double access")

In addition to PRESRus, Russian has the deictic present $\mathrm{N}$, which also checks the feature $\mathrm{uN}$. In complement clauses, $\mathrm{N}$ is ruled out for type reasons. Therefore, the temporal argument of PRESRus at DS is always PRO.

(52) Vanja skazal ${ }_{\text {PAST-PF, }}$ čto Maša poët.

(lit.) John said that Mary sings.

$\mathrm{N} \lambda_{1} \mathrm{P}\left(t_{1}\right) \lambda_{2}$ John said $\left(t_{2}\right)$ PRO $\lambda_{3} \operatorname{PRES}_{\text {Rus }}\left(t_{3}\right) \lambda_{4}$ Mary $\operatorname{sings}\left(t_{4}\right)$

iP uP iN uN

$\lambda w .\left(\exists t<s^{*}\right)$ John says in $w$ at $t\left[\lambda w_{1} \lambda t_{1}\right.$. Mary sings in $w_{1}$ at $\left.t_{1}\right]$

FIGURE 14: "Present under past" in Russian (simultaneous)

The morphological present of the embedded verb is locally licensed by PRESRus in (52). Consider now the anteriority construction in (53) below. Since Russian is a non-sот-language, the verbal quantifier "skazal" ("said") does not transmit its feature uP. Therefore we need an additional $\mathrm{P}$ in the complement, which gives us the backward shifting.

(53) Vanja skazal ${ }_{\text {PAST-PF, }}$, čto Maša pela PAST-IMPF. $_{\text {. }}$

(lit.) John said that Mary sang [or was singing].

$\mathrm{N} \lambda_{1} \mathrm{P}\left(t_{1}\right) \lambda_{2}$ John said $\left(t_{2}\right)$ PRO $\lambda_{3} \mathrm{P}\left(t_{3}\right) \lambda_{4}$ Mary sang $\left(t_{4}\right)$

iP uP iP uP

$\lambda w .\left(\exists t<s^{*}\right)$ John says in $w$ at $t\left[\lambda w_{1} \lambda t_{1} \cdot\left(\exists t_{2}<t_{1}\right)\right.$ Mary sings in $w_{1}$ at $\left.t_{2}\right]$ FIGURE 15: "Past under past" in Russian (anterior)

\section{[3.5] Insertion of covert past}

As shown in (von Stechow 2005), we must allow for the insertion of covert future operators in modal contexts. We have seen in section [2.3] above that this can also be the case in the complements of intensional attitude verbs. To a certain extent, we must make a similar allowance for covert past operators. As argued in 
(Paslawska \& von Stechow 2003) and (Grønn 2007), we need a covert relative past operator in a language like Russian which lacks a composite perfect. We can insert a RELATIVE PAST under past or future to obtain a semantic PLUPERFECT or FUTURE PERFECT. An illustration from subordinate tense is provided below, cf. example (54) and Figure 16.

(54) I my nadeemsja ${ }_{\mathrm{PRES}}$ na to, čto uže do prazdnika každyj veteran polučit $t_{\mathrm{FUT}}$ PF svoj order. (Internet)

'We hope that already before the anniversary each veteran will have received his warranty for living accommodation.' (our translation)

N nadeemsja, čto $\varnothing$-tense FUT PAST uže do prazdnika polučit (Russian)
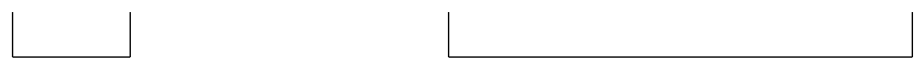

FIGURE 16: Insertion of covert relative past in Russian complements

How do we know that we have to insert a covert PAST in this construction? The particle uže ("already") requires a stative as evidenced by the following contrast in English:

(55) Every veteran will already *receive/OK have received warranty.

The perfect HAVE converts the achievement "receive warranty" into a stative. Without the perfect the sentence is ungrammatical.

\section{[4] CHALLENGES TO RUSSiAN AS A NON-SOT LANGUAGE}

According to the sот parameter, "past under past" in Russian should give us a shifted anteriority reading. Claims in the literature to the contrary - i.e., that "past under past" in Russian sometimes allows for a simultaneous interpretation - at first seem to challenge our theory. We will show that three kinds of explanations in defence of the sот parameter are available depending on the data under discussion:

- It follows from our semantics of aspect that complements which carry imperfective aspect may still be compatible with a simultaneous event interpretation despite the topic time in the complement being backward shifted. Hence these cases are not in contradiction with the soт parameter.

- The matrix is not a verbal quantifier, hence not subject to the sot parameter. 
- The past tense complement has an independent de re interpretation, hence not subject to the sot parameter.

\section{[4.1] Shifting under attitudes and aspect in Russian}

Altshuler (2008) objects against the traditional view that "past under past" means backward shifting in non-sot languages like Russian. He says that embedded imperfectives in the past can have a simultaneous or a backward shifted reading. Embedded perfectives are always anterior.

To simplify the exposition, we have not given a semantic analysis of aspect so far. The fact that we can have a kind of "simultaneity" with "past under past" in Russian if the embedded verb is imperfective is straightforwardly explained by considering the meaning of the imperfective.

Aspect

a. Imperfective

$$
\llbracket \mathrm{IMPF} \rrbracket=\lambda w \lambda E_{\mathrm{vt}} \lambda t .(\exists e)[E(e) \& t \subseteq \tau(e)] \quad \text { type (vt, it) }
$$

b. Perfective

$$
\llbracket \mathrm{pF} \rrbracket=\lambda w \lambda E_{\mathrm{vt}} \lambda t .(\exists e)[E(e) \& \tau(e) \subseteq t] \quad \text { type (vt, it) }
$$

We use $E$ for properties of events. $\tau(e)$ is the running time of the event $e$. The meaning of the imperfective is crudely simplified, but good enough for our purposes. $^{23}$

Here are some examples of the kind which motivated Altshuler's objections to the treatment of Russian as a non-soт language:

(57) E Harris said that, to himself, it was always a mystery how people managed to get sick at sea. (Jerome K. Jerome, "Three Men in a Boat")

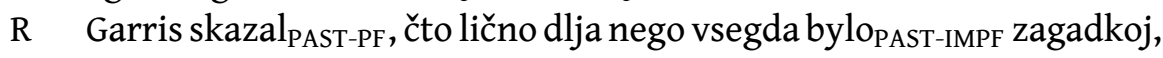
kak èto ljudi uchitrjajutsja PRES-IMPF $_{\text {stradat' }}$ INF morskoj bolezn'ju.

(58) E Poor fellow, I thought my own trouble was bad enough, but his ... (Bram Stoker, Dracula)

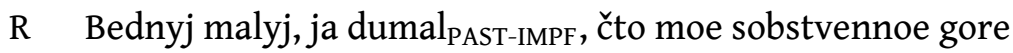
bylopAST-IMPF dostatočno veliko, no ego!

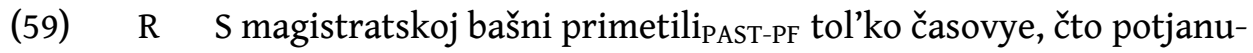

[23] The imperfective has at least three different uses:

- Progressivity: this interpretation needs an intensionalisation in the style of (Dowty 1979).

- Habituality; for recent proposals, see (Bary 2009) and (Deo 2006).

- For Russian, one also has to consider the general-factual interpretation, see (Grønn 2003).

It is a matter of dispute whether a unified account can be given for all these readings. 


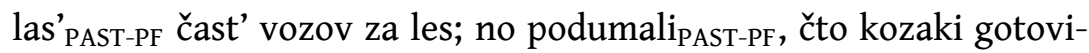
lis' ${ }_{\text {PAST-IMPF }}$ sdelat' ${ }_{\text {INF }}$ zasadu; tože dumal ${ }_{\text {PAST-IMPF }}$ i francuzskij inžener. (Nikolaj Gogol', “Taras Bul'ba”)

E From the tower of the town hall the sentinel only perceived that a part of the waggons had been dragged into the forest; but it was thought that the Cossacks were preparing an ambush - a view taken by the French engineer also.

In the examples above, we have "past under past", but the imperfective state in the complement clearly holds before, at and, perhaps, after the matrix event. This allows for an analysis where the topic time of the complement (a proper subinterval of the (progressive) state) precedes the topic time of the matrix. We show how this works by giving an analysis of the last example above: ${ }^{24}$

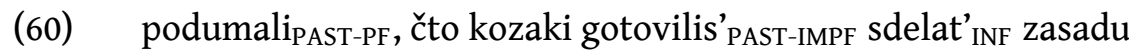
(it was thought that the Cossacks were preparing an ambush) $\mathrm{N} \lambda_{0} \mathrm{P}\left(t_{0}\right) \lambda_{1}$ podumali $\left(t_{1}\right) \mathrm{PRO}_{2} \mathrm{P}\left(t_{2}\right) \lambda_{4} \operatorname{IMPF}\left(t_{4}\right) \lambda_{5}$ gotovilis' $\left(t_{5}\right)$ $=\lambda w \cdot\left(\exists t<s^{*}\right)$ they think in $w$ at $t\left[\lambda t_{1} \lambda w_{1} \cdot\left(\exists t_{2}<t_{1}\right)(\exists e)\left[t_{2} \subseteq \tau(e) \&\right.\right.$ $e$ is preparing of an ambush in $\left.\left.w_{1}\right]\right]$

We have backward shifting in the embedded clause. But since the VP expresses a progressive state and the topic time is in the time of the state, the state might continue at the "subjective now" $t_{1}$. This gives us the feeling that the reading is simultaneous. This is a point stressed emphatically in (Klein 1994).

Note that according to our theory, the past progressive in the English translation (59E) can, strictly speaking, also get its simultaneous reading - in terms of temporal overlap between the matrix and complement events - through a backwarded shifted topic time, as in Russian. As formulated above in section [1.1], our sот parameter does not require long-distance feature transmission for English, hence it does not by itself block the insertion of a local semantic past in the complement. Our theory does not say where the semantic tense is located at LF. ${ }^{25}$ The two simultaneous readings for English obtained through non-local or local agreement are indeed hard to distinguish. For Russian, on the other hand, the sOT parameter forces local binding from a semantic PAST in the complement.

As pointed out by a reviewer, temporal feature transmission from the matrix forces a simultaneous interpretation for the English sentence (59E), while the proposed truth conditions for (59R) do not. We think that this is as it should be. Indeed, although (59E) is an adequate translation of (59R), the two constructions are not completely equivalent. While the English translation (in principle) allows

[24] Recall from section [3] that $\mathrm{PRO}_{i}$ can be read as $\lambda_{i}$. The official notation would have an erased PRO and $\lambda_{i}$. Often we simply write $\lambda_{i}$.

[25] In our system, feature transmission is not optional, but there may be different possible licensers. 
for two different tense configurations (cf. previous paragraph), the Russian original (in principle) allows for two different aspectual configurations. As argued in (Grønn 2007), the so-called "factual" imperfective past in Russian (i.e., IMPF with a complete event interpretation) is, again in principle, i.e., semantically, compatible with a backshifted relative past configuration. However, due to competition from the perfective past, which explicitly encodes a proper backward shifted reading under attitudes, the imperfective is often pragmatically strengthened to encode a simultaneous (progressive) reading.

Thus, if the embedded past VP in Russian is in the perfective aspect, we always have the anterior reading. This was confirmed by our survey of the data in section [2]. We give the analysis of one example here:

(61) E I've told them I've found someone. (Helen Fielding, "Bridget Jones's Diary")

R Ja uže skazala ${ }_{\text {PAST-PF }}$ im, čto našla PAST-PF $_{\text {koj-kogo. }}$

$$
\begin{aligned}
& \mathrm{N} \lambda_{0} \mathrm{P}\left(t_{0}\right) \lambda_{1} \text { ja skazala }\left(t_{1}\right) \mathrm{PRO}_{2} \mathrm{P}\left(t_{2}\right) \lambda_{4} \mathrm{PF}\left(t_{4}\right) \lambda_{6} \text { našla koj-kogo }\left(t_{6}\right) \\
& =\lambda w\left(\exists t<s^{*}\right) \text { I tell in } w \text { at } t\left[\lambda t_{1} \lambda w_{1} .\left(\exists t_{2}<t_{1}\right)(\exists e)\left[\tau(e) \subseteq t_{2} \&\right.\right. \\
& \text { I find someone } \left.\left.(e) \text { in } w_{1}\right]\right]
\end{aligned}
$$

It is clear that the reading has to be anterior because the backward shifted interval contains a complete or "quantised" event. A property of events is "quantised" if it does not apply to subintervals of its running time.

\section{[4.2] Tense under perception verbs in Russian}

Not every verb that selects a $\mathrm{CP}$ is a verbal quantifier. Perception verbs are not verbal quantifiers in their prototypical use; hence we should not be surprised to find "past under past" with a simultaneous interpretation in Russian. Nevertheless, constructions with perception verbs often follow the familiar patterns predicted by the sot parameter. We will review the different data below.

Simultaneous interpretation under past perception verbs: "past under past" Khomitsevich (2007) observes that "past under past" frequently expresses simultaneity in perception constructions even for embedded achievements or accomplishments. She correctly claims that this is an effect of the semantics: on the default, direct perception reading, the fact/event perceived must be simultaneous with the perception. In this construction, the complementiser in Russian is typically "kak" ("how") instead of "čto" ("that"). Here are some examples from our parallel corpora:

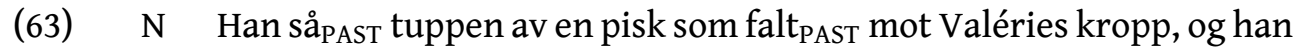
hørte $e_{\mathrm{PAST}}$ at mannen roste $\mathrm{PAST}_{\text {det }}$ detygge trynet hennes.

(Nikolaj Frobenius, "Latours katalog") 
E He saw the whip descending on Valérie's body and heard the man extolling her ugly face.

G Nun ließ $\beta_{\text {PAST }}$ der Mann die Peitsche auf Valéries Körper herabsaus-

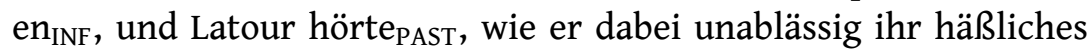
Gesicht lobte PAST $_{\text {. }}$

F Il vit PAST-PF $_{\text {l'extrémité d'un fouet s'abattre }}$ INF $_{\text {sur le corps de Valérie }}$ et entendit PAST-PF $_{\text {la voix de l'homme qui louait }}$ PAST-IMPF son affreux groin.

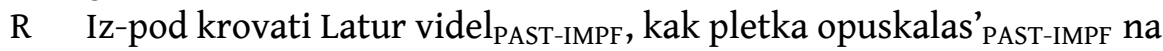

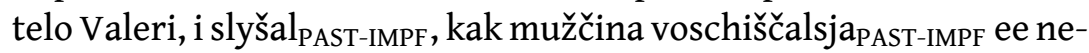
krasivym licom.

(64) N Til og med da han så $a_{\text {PAST }}$ at hun red PAST $_{\text {PA }}$ ut av gården, kunne $e_{\text {PAST-MODAL }}$ han ha INF-AUX $_{\text {gjort }}$ PART det. (Herbjørg Wassmo, "Dinas bok")

E Even when he saw her riding out of the courtyard, he could have done it.

G Sogar als er $\operatorname{sah}_{\text {PAST }}$, daß sie fortritt PAST, hätte $_{\text {PAST-SUBJ-AUX }}$ er noch etwas tun $_{\text {INF }}$ können $n_{\text {PAST-SUBJ-MODAL. }}$.

F Même quand il la vit PAST-PF $_{\text {partir }}$ INF, il avait $_{\text {PAST-IMPF }}$ encore une chance.

R Nakonec on uvidel PAST-PF, $_{\text {, kak ona vyechala }}$ PAST-PF so dvora, no daže togda ešče možno bylopAST-IMPF ostanovit' ${ }_{\text {INF }}$ ee.

(65) N Det siste han kjente PAST $_{v^{2}} \operatorname{rar}_{\text {PAST }}$ at mannen fjernet $t_{\text {PAST }}$ papirene fra frakkelommen hans. (Nikolaj Frobenius, "Latours katalog")

E His last conscious perception was of the man removing the papers from his coat pocket.

G Das letzte, was er spürte PAST, $_{\text {, }}$ war $_{\text {PAST }}$, daß ihm der Mann etwas aus der Jackentasche zog PAST. $_{\text {. }}$

F La dernière chose qu'il sentit $t_{\text {PAST-PF }}$ était $t_{\text {PAST-IMPF }}$ que l'homme extray-

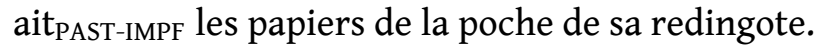

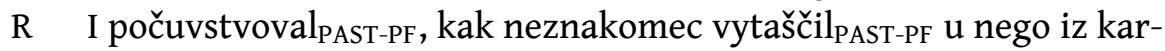
mana dokumenty.

Simultaneous interpretation under past perception verbs: "present under past" With a "present under past" in Russian, the perception verb construction is reminiscent of verbs of attitudes. The perspective is not that of the speaker, but of the perception holder, hence we get a kind of evidential reading.

(66) N Men han så PAST at hun ikke $\operatorname{var}_{\text {PAST }}$ helt seg selv. (Herbjørg Wassmo, "Dinas bok")

E But he saw that she was not completely herself.

$G \quad$ Aber er sah ${ }_{\text {PAST }}$, daß sie nicht ganz sie selbst war ${ }_{\text {PAST }}$. 
F Mais il vit PAST-PF $_{\text {Pien qu'elle n'était }}$ PAST-IMPF pas tout à fait elle-même.

$\mathrm{R} \quad$ No on videl $\mathrm{PAST-IMPF}$, čto ona sovsem ne takaja, kak vsegda.

Note also that the distinction between perception verbs and factives is sometimes very subtle. Evidence for knowing can be visual or acoustic. The Russian translator in (67R) below can therefore use a perception verb to convey the meaning of the factive verb in the original:

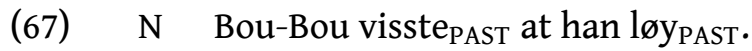

(Nikolaj Frobenius, "Latours katalog")

E Bou-Bou knew he was lying.

$G$ Doch Bou-Bou wußte PAST, daß er $\log _{\text {PAST. }}$.

$\mathrm{R} \quad \mathrm{Bu}$-Bu videla $a_{\text {PAST-IMPF }}$, čto on lžet $t_{\text {PRES-IMPF. }}$.

The evidence for him being a liar in (67R) can be indirect. Constructions with perception verbs are therefore often ambiguous between direct perception and indirect perception.

In analogy with complements of attitude verbs, we find the expected complementiser "čto" ("that") in the two previous Russian examples. The facts are more complicated though, as witnessed by the next example:

(68) N De hørte $e_{\text {PAST }}$ at hun gikk $k_{\text {PAST }}$ ute og inne.

(Herbjørg Wassmo, "Dinas bok")

E They heard her pacing outside and inside.

$G \quad$ Man hörte PAST $_{\text {sie drinnen und draußen herumlaufen }}$ INF.

$\mathrm{F}$ On l'entendait PAST-IMPF $_{\text {aller }}$ INF $_{\text {et venir }}$ INF.

$\mathrm{R} \quad$ Ljudi slyšali $i_{\text {PAST-IMPF }}$, kak ona to vychodit PRES-IMPF $_{\text {iz domu, to snova }}$ vozvraščaetsja PRES-IMPF $\mathrm{v}$ dom.

In (68), only the Norwegian original ("past under past") and the Russian translation ("present under past") have a finite complement clause. With the non-finite complements in the English, German and French translations, the perception construction can only have a direct perception reading. The Russian complementiser "kak - how/as" - instead of "čto - that" - is also an indication of direct perception. Given a Higginbotham style analysis of perception verbs (see below), one would expect a "past under past" construction also in Russian. The translator's choice of "present under past" makes the construction more "vivid" and similar to attitude verbs: the complement is reported from the perspective (acoustic alternatives) of the perception holder.

Analysis of tense under perception verbs

Thus, perception verbs express simultaneity either by embedding a past or a present. If these verbs were analysed like attitudes, present would be expected, with 
a sort of evidential reading. If past and present were freely interchangeable in these constructions without a change in meaning, then that would be a problem. We suggest that the alternation may to some extent reflect an ambiguity between direct perception from the speaker's perspective ( $\Rightarrow$ "past under past") and visual/acoustic alternatives from the perception holder's perspective ( $\Rightarrow$ "present under past").

Our analysis of direct perception closely follows (Higginbotham 1983). ${ }^{26} \mathrm{Hig}-$ ginbotham analyses perceptions as a relation between an individual and an event, the eventive reading. The analysis will entail that these verbs are (normally) not verbal quantifiers and hence not subject to the sот parameter. Let us relate the discussion to a toy example from Altshuler (2004):

(69) a. Dina videla PAST-IMPF, $_{\text {, kak (čto) voda lilas' }}{ }_{\text {PAST-IMPF }}$ iz vedra.

'Dina saw how (that) water was pouring [poured] from the basket'

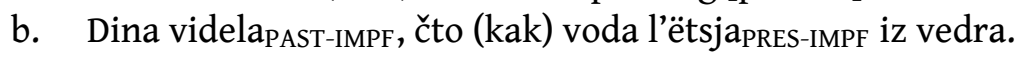

'Dina saw that (how) water was pouring [pours] from the basket'

The complement in (69a) describes an event and may, of course, localise it in time. We expect a de re past in the complement, given that the truth-condition of (69a) is something like this:

(70) There was a water pouring $e$ \& Dina saw $e$.

On this account, it is obvious that "see" is not a (normal) verbal quantifier, at least when the verb is used to denote direct perception. This analysis of the construction has interesting consequences for the semantics of aspect. Here is the result we want for (69a) (in Altshuler's Russian example the perception verb itself is also in the imperfective aspect):

$$
\begin{aligned}
& \lambda w(\exists e)\left(\exists t<s^{*}\right)[t \subseteq \tau(e) \& \text { water pouring } w \\
& w \\
& \&\left(\exists t_{1}<s^{*}\right)\left(\exists e_{1}\right)\left[t_{1} \subseteq \tau\left(e_{1}\right) \& \text { see }_{w}\left(\text { Dina, } e_{1}, e\right)\right]
\end{aligned}
$$

We have two independent deictic pasts, so no temporal agreement is needed. Furthermore, the existential quantifier on top binds the variable $e$ that occurs as an argument of the aspect in the the subordinate clause and as the direct object of the matrix verb. This means that the event variable in the aspect is not always locally bound by an existential quantifier. Accordingly, we have to modify the logical type of the aspectual operator:

Aspect

a. $\quad$ usually: $\llbracket \mathrm{IMPF} \rrbracket=\lambda w \lambda E_{\mathrm{vt}} \lambda t .(\exists e)[E(e) \& t \subseteq \tau(e)] \quad$ type (vt, it)

[26] Factive verbs have a related analysis but exhibit an additional complication and are therefore considered later. 

here: $\llbracket \mathrm{IMPF} \rrbracket=\lambda w \lambda e \lambda t \lambda E_{\mathrm{vt}} \cdot E(e) \& t \subseteq \tau(e)$
type $(\mathrm{v}(\mathrm{i}(\mathrm{vt}, \mathrm{t})))$
b. usually: $\llbracket \mathrm{pF} \rrbracket=\lambda w \lambda E_{\mathrm{vt}} \lambda t .(\exists e)[E(e) \& \tau(e) \subseteq t]$
type (vt, it)
here: $\llbracket \mathrm{PF} \rrbracket=\lambda w \lambda e \lambda t \lambda E_{\mathrm{vt}} \cdot E(e) \& \tau(e) \subseteq t$
type $(\mathrm{v}(\mathrm{i}(\mathrm{vt}, \mathrm{t})))$

We can regain the familiar existential analysis for aspect by existential closure of the variable $e$.

The complement clause is headed by "kak" ("how"), here analysed as an existential quantifier over events, as in (73). The compositional build up of the LF for the complement clause is depicted in Figure 17.

$$
\llbracket \mathrm{kak} \rrbracket=\lambda P_{\mathrm{vt}} \lambda Q_{\mathrm{vt}}(\exists e)[P(e) \& Q(e)] \quad \text { type (vt(vt,t)) }
$$

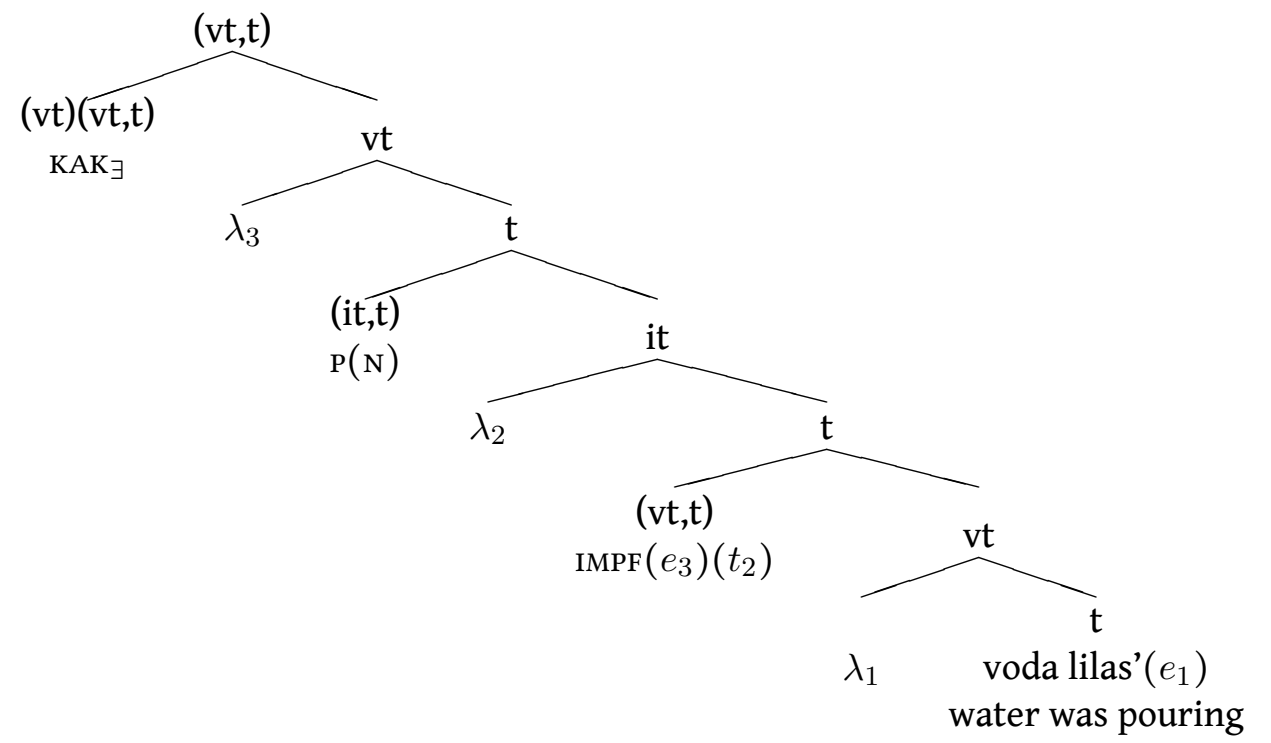

FIGURE 17: Compositional derivation of the past complement in (69a)

The "kak"-clause is the object of the perception verb videla", which has the following semantics:

$$
\begin{aligned}
& \llbracket \text { videla }^{1} \rrbracket=\lambda w \lambda e_{1} \lambda e_{2} \lambda x \cdot e_{2} \text { is a seeing of } e_{1} \text { by } x \text { in } w \quad \text { type }(\mathrm{v}(\mathrm{v}(\mathrm{et}))) \\
& \text { features: uP, uIMPF }
\end{aligned}
$$

In order to be able to have the "kak/how"-clause as an object, we must QR the generalised quantifier from the object position. We end up with the LF in Figure 18 on the facing page, which eventually brings us back to the truth-conditions which we started out with in (71).

A note concerning feature transmission is in order: Temporal features are transmitted across the aspect operator to the variable that the latter binds. Thus 


$$
\begin{aligned}
& {\left[\mathrm{CP} \mathrm{KAK}_{\exists} \lambda_{3} \mathrm{P}(\mathrm{N}) \lambda_{2} \operatorname{IMPF}\left(e_{3}\right)\left(t_{2}\right) \lambda_{1} \text { voda lilas' }\left(e_{1}\right)\right]} \\
& \text { iP iIMPF uP uP, uIMPF } \\
& \lambda_{4}\left[\mathrm{~s} P(\mathrm{~N}) \lambda_{5}\left(\exists_{6}\right) \operatorname{IMPF}\left(e_{6}\right)\left(t_{5}\right) \lambda_{7} \text { Dina videla }\left(e_{4}\right)\left(e_{7}\right)\right] \\
& \text { iP } \text { iIMPF uP uP, uIMPF }
\end{aligned}
$$

FIGURE 18: LF of (69a) with temporal and aspectual features

the aspect operator transmits two kinds of features: its own aspect feature and the temporal feature inherited from the semantic tense of the sentence.

This analysis explains the fact that "past under past" may express simultaneity, i.e., direct perception, in perception constructions. Let us now turn to "present under past" and example (69b).

Indirect perception verbs are verbal quantifiers. Their analysis is similar to believing or knowing. The possible difference is that the attitude is based on visual, acoustic or other sensomotoric evidence. For instance, for the truth of $(69 \mathrm{~b})$ it is sufficient to see that the desk under the basket gets more and more wet. In the limiting case the evidence is direct, in which case the "seeing that" is something like realizing by direct visual evidence. There might be a de re variant as well, similar to our de re analysis of factive verbs (See section [4.3] below). ${ }^{27}$

Thus, since perception verbs with subordinate present are verbal quantifiers, they have the standard semantic assumed for attitudes. For concreteness, we indicate the lexical entry for videla in (69b):

$$
\begin{aligned}
& \llbracket \text { videla }^{2} \rrbracket=\lambda w \lambda P_{\mathrm{s}(\mathrm{it})} \lambda t \lambda x \cdot\left(\forall w_{1}\right)\left(\forall t_{1}\right)\left[\left(w_{1}, t_{1}\right) \in \operatorname{Acc}_{x}(w, t) \rightarrow P\left(w_{1}\right)\left(t_{1}\right)\right], \\
& \text { where } \operatorname{Acc}_{x}(w, t) \text { are the world-times compatible with the visual evidence } \\
& \text { that } x \text { has in } w \text { at time } t .
\end{aligned}
$$

We assume that "kak/čto" is a complementiser without meaning in constructions involving these verbs. Under these assumptions, (69b) is analysed exactly as any belief-sentence and means: ${ }^{28}$

[27] The relevant paraphrase for the double access reading of "present under past" is this: "There is a state $s$ of water pouring and she saw $s$ ". A present state of water pouring may have had its beginning some time ago, and she saw that very state in the past. This is precisely the idea behind the double access reading of "John believed that Mary is pregnant.", cf. (Abusch 1997).

[28] We ignore the event arguments and aspects in (76). Concerning tense, we repeat from above what should be clear by now: Since the complement clause is tenseless, it has to be controlled by the matrix tense, hence we have dependent tense and the sот parameter applies. As we did for present tense complements under normal attitude verbs in Russian, we must insert the identity function PRESRus in order to license the present tense morphology in the complement. 
$\llbracket(69 \mathrm{~b}) \rrbracket=\lambda w \cdot(\exists t)\left[t<t_{0} \&\left(\forall w_{1}\right)\left(\forall t_{1}\right)\left[\left(w_{1}, t_{1}\right) \in \operatorname{Acc}_{\text {Dina }}(w, t) \rightarrow\right.\right.$ water is pouring out of the basket in $w_{1}$ at $\left.\left.t_{1}\right]\right]$

If the cognitive evidence is reliable, the complement of a perception verb is true and there is virtually no difference in truth conditions between the direct and indirect perception construction. This is witnessed by the fact that both constructions can be conjoined, i.e., we find alternation between "past over past" and "past over present", as in (77):

(77) $\mathrm{R}$ Ona gljadela $a_{\text {PAST-IMPF, }}$ kak sizye kol'ca ot sigary Azarello

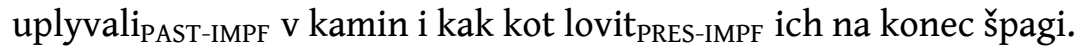
(Michail Bulgakov, "Master i Margarita")

E She watched as Azarello blew (Rus: past!) smoke-rings at the fireplace and the cat spiked (Rus: present!) them on the end of his sword.

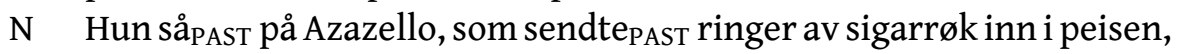

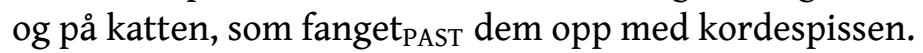

\section{[4.3] Tense under factive verbs}

Our informal corpus study in section [2] shows that many authentic examples with factives comply with the patterns characteristic of attitude verbs in Russian, i.e., "present under past" is used for a simultaneous interpretation.

However, as with perception verbs, we find data with "past under past" and a "simultaneous" interpretation also in factive constructions. We will argue that these data are not counterexamples to our sot theory, since factives have a special semantics which is responsible for this vacillation. Here are some relevant data with "past under past" in Russian:

(78) $\mathrm{N}$ Alle visste $\mathrm{PAST}_{\mathrm{PAT}}$ at lensmannsfrua var $_{\mathrm{PAST}}$ flere måneder på vei da hun ble $_{\text {PAST-AUX }}$ skoldet $t_{\text {PART }}$ i hjel. (Herbjørg Wassmo, "Dinas bok")

E Everyone knew the sheriff's wife was several months pregnant when she was scalded to death.

$G \quad$ Alle wußten ${ }_{\text {PAST }}$, daß die Lehnsfrau schon mehrere Monate schwanger war PAST, $_{\text {, als sie }}$ zu Tode verbrüht $t_{\text {PART }}$ wurde PAST-AUX. $_{\text {. }}$

R Vse znali PAST-IMPF, $_{\text {čto žena lensmana byla }}$ PAST-IMPF beremenna, kogda obvarilas'PAST-PF ščeločjju.

(79) $\mathrm{R} \quad$ On ponjal $\mathrm{PAST}_{\mathrm{PF}}$, čto ona echala $a_{\mathrm{PAST} \text {-IMPF }} \mathrm{v}$ Ergušovo so stancii železnoj dorogi. (Lev Tolstoj, “Anna Karenina”)

E He understood that she was driving to Ergushovo from the railway station.

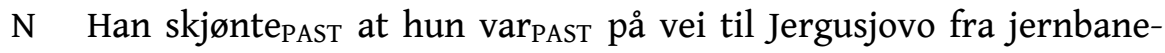
stasjonen. 


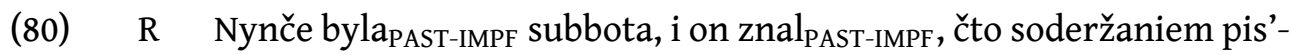
ma byli PAST-IMPF $_{\text {upreki } v \text { tom, čto on ne vernulsja }}$ PAST-PF vovremja. (Lev Tolstoj, "Anna Karenina")

E Today was Saturday, and he knew that the letter contained reproaches for not being back at the time fixed.

$\mathrm{N}$ I dag var PAST $_{\text {Pet }}$ lørdag, og han visste PAST $_{\text {a }}$ at brevet inneholdt $t_{\text {PAST }}$ bebreidelser over at han ikke var PAST-AUX $_{\text {kommet }}$ PART hjem i rett tid.

Khomitsevich (2007) writes that embedded past and present are freely interchangeable in Russian in these constructions without change in meaning. Indeed, the difference in truth conditions may be negligible, but the derivation at LF must still be different. Note that as a first try we could naïvely adopt the same explanation for these data as for the examples discussed in section [4.1] above where a simultaneity reading occurred with imperfective past complements under attitude verbs. For those cases we pointed out that the sот parameter only requires the topic time of the complement to precede the topic time of the matrix, hence we can still have a kind of simultaniety of the events described in the matrix and complement. However, this approach would not do justice to the semantics of the factive construction. Our semantics for factives will make it clear that we have an independent de re past in the complement of examples like (78) - (80), similar to what we observed with "past under past" and perception verbs in the previous section. Thus, we agree with Khomitsevich that "past under past" with factives is never a (non-local) tense agreement phenomenon in Russian.

Our analysis of these readings will follow Kratzer (1990)'s analysis of factual belief, according to which one of the roles of the complement clause is to describe the known fact. This will bring the complement clause in a transparent position and explain why the subordinate tense is interpreted independently from the matrix tense. In other words, the temporal locations of the two facts are described independently, which does not exclude the two facts from overlapping in time (simultaneity).

In order to understand the semantic rationale behind these findings, we remind the reader of the analysis of facts given in (Kratzer 1990). Consider the following sentence and its analysis:

$$
\text { John knew that it was raining. }
$$
a. There was a state/event $e$, which was a raining, and
b. John was acquainted with $e$, and
c. John believed of $e$ the property of raining.

The complement clause is used in condition (a) and in condition (c). (a) is a purely extensional environment and the interpretation of the past tense is independent of the tense of the main clause. (c) is an intensional environment, where the com- 
plement clause serves for the description of a tenseless property (a zero tense; a relative bound present in Russian).

Given that the complement clause has to fulfil two roles for getting the content right, we face a dilemma of expressibility: if the complement is in the present, the complement can describe only condition (c) correctly. If the complement is in the past, it can describe only condition (a).

In order to implement the two strategies of projecting the complement clause, we will adopt a trick: if the visible complement clause is in the past, it will describe the res, i.e., the event/situation the subject holds the attitude of, and the property believed of the res will be represented by a free property variable, which is supposed to be the tenseless counterpart of the complement. If the complement is in the present, it will be the property attributed to the res and the tensed counterpart will be represented by a free property variable. Now, let us see how this works with a minimal pair from Russian (cf. example (10) above):

On znal PAST-IMPF, $_{\text {čto ona stojala }}$ PAST-IMPF $u$ okna.

'He knew she was standing by the window.'

The analysis is sketched in Figure 19 on the next page. The crucial points to notice are the following: We are flexible in choosing between the two versions of the aspects from (72). In the complement, we have the new version where the event argument is not locally bound, while in the matrix, aspect has its traditional logical type. In the end, the structure gives us existential closure of the event argument in both cases. The complementiser "čto" is a $\lambda$-operator (an abstraction over the event variable). We assume that $Q$ in (83) gets the following interpretation:

$$
Q=\lambda w \lambda e \exists t[\tau(e) \supset t \& \text { stand_at_window }(\text { she }, e, w)]
$$

The relevant semantic rule is this:

$$
\begin{aligned}
& \text { de re knowledge } 1 \llbracket \operatorname{know}_{Q}^{1} \rrbracket=\lambda w \lambda e \lambda P_{\mathrm{sv}, \mathrm{t}} \lambda x .\left(\exists e_{1}\right)\left[P(w)\left(e_{1}\right)\right. \\
& \left.\& \text { acquainted }\left(x, e_{1}, w\right) \& \text { believe_of }\left(x, e, e_{1}, Q, w\right)\right]
\end{aligned}
$$

This is the version where the past in the complement denotes a tense that is independent from the matrix tense. Hence we can have simultaneity, cf. the result we obtain from computing the derivation in Figure 19 on the facing page:

$$
\begin{aligned}
& \lambda w \cdot\left(\exists t<s^{*}\right)(\exists e)\left[\tau ( e ) \supset t \& ( \exists e _ { 1 } ) ( \exists t _ { 1 } < s ^ { * } ) \left[\tau\left(e_{1}\right) \supset t_{1} \&\right.\right. \\
& \text { stand_at_window } \left.\left(\text { she, } e_{1}, w\right)\right] \& \text { acquainted }\left(\text { he, } e_{1}, w\right) \\
& \text { \& believes_of } \left.\left(\text { he, } e, e_{1}, Q, w\right)\right]
\end{aligned}
$$

The relation believes_of (he, $\left.e, e_{1}, Q, w\right)$ can be analysed further in the style of (Lewis 1979). This is rather complicated because it involves the particular relation 


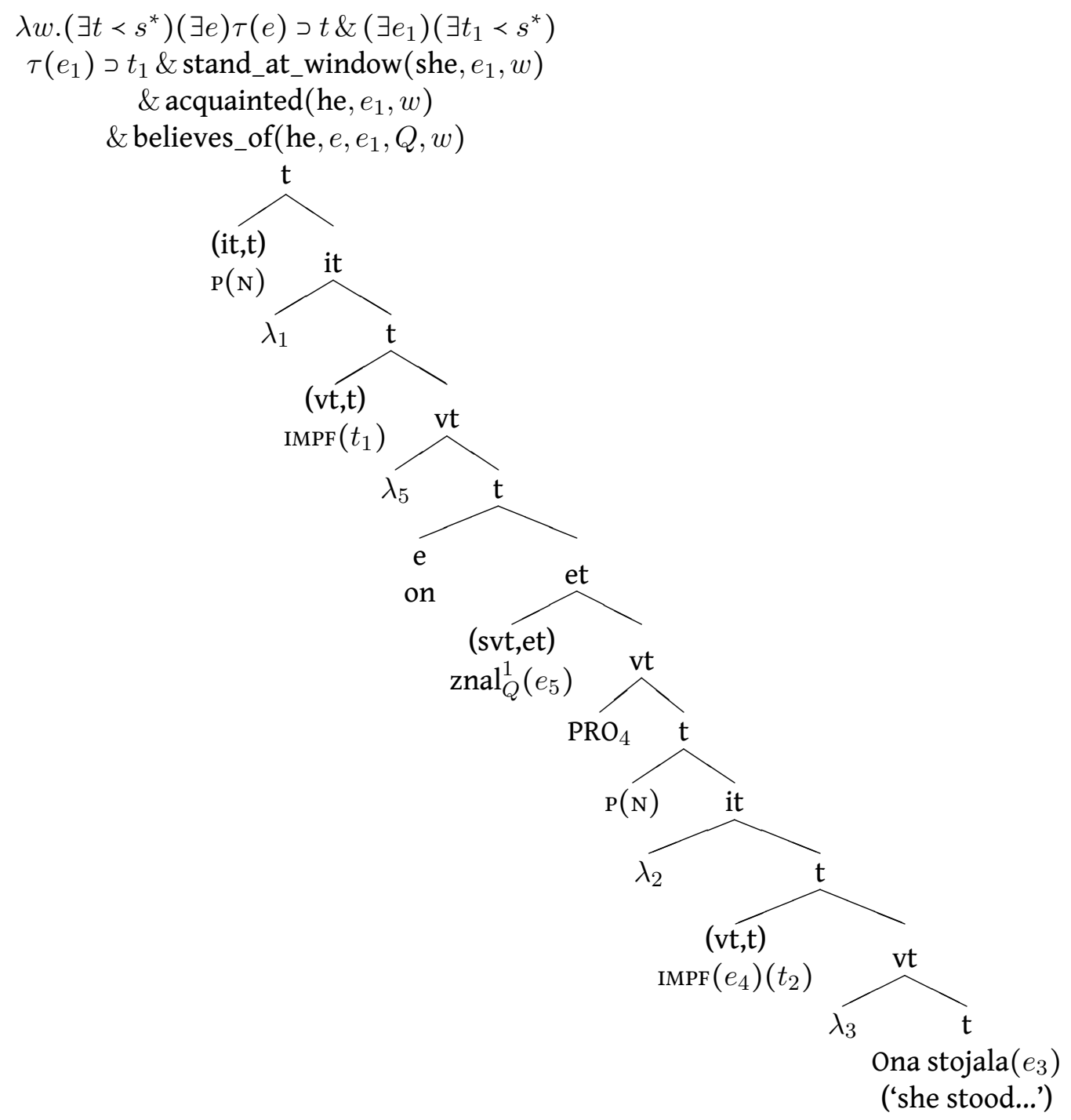

FIGURE 19: Compositional derivation of "past under past" in (83). 


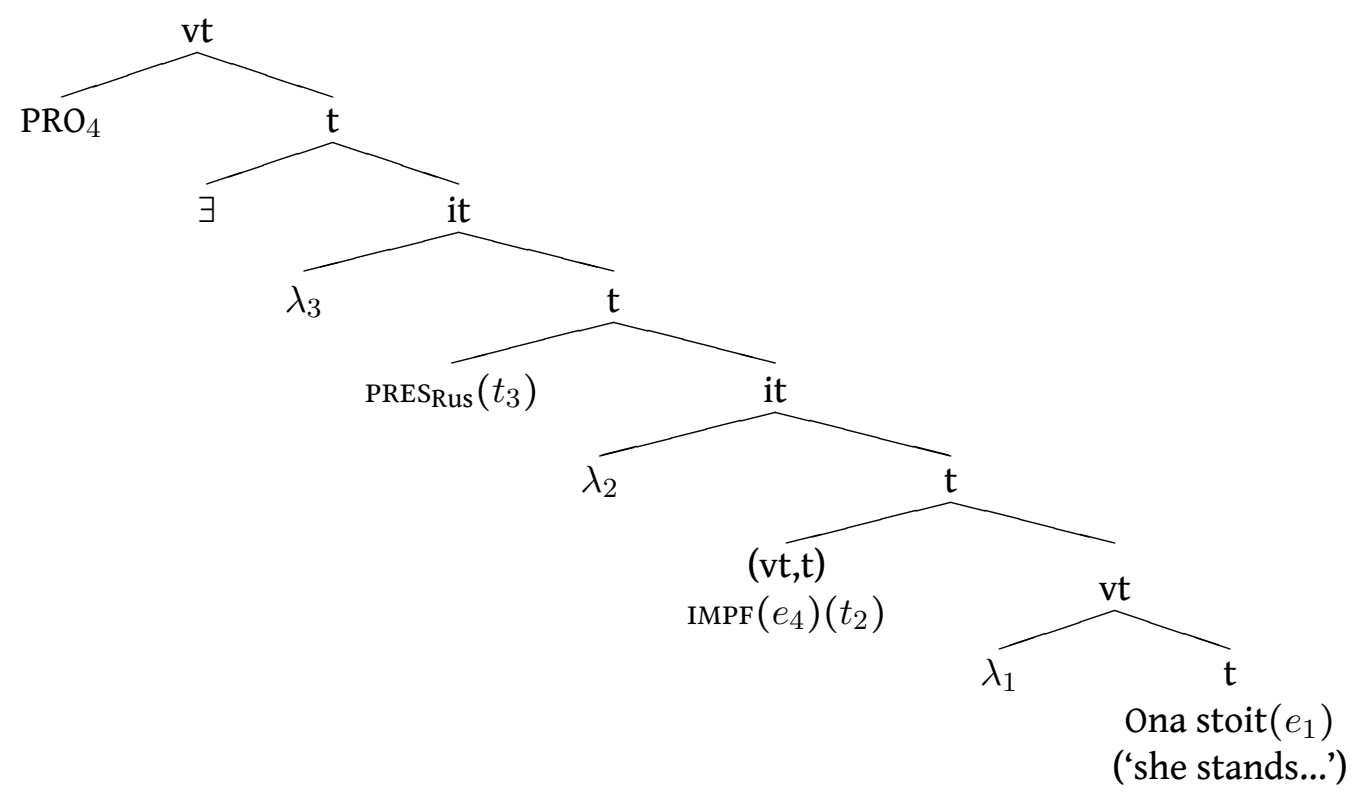

FIGURE 20: Compositional derivation of the present complement under factives

of acquaintance in question. Here it can be paraphrased roughly as "he believed being in a state of acquaintance with a situation that was a standing at the window of her".

Next, consider the case where we have present tense in the complement clause: (87) On znal PAST-IMPF, čto ona stoit $_{\text {PRES-IMPF }} u$ okna.

The upper part of the LF tree is exactly as before, but the complement clause is in the present. Thus, the complement depicted in Figure 20 is the overt version of our former property $Q$. We now need a new rule where $Q$ plays the role of the past tensed counterpart of this property:

$$
\begin{aligned}
& \text { de re knowledge } 2 \llbracket \operatorname{know}_{Q}^{2} \rrbracket=\lambda w \lambda e \lambda P_{\mathrm{sv}, \mathrm{t}} \lambda x .\left(\exists e_{1}\right)\left[Q(w)\left(e_{1}\right)\right. \\
& \left.\& \text { acquainted }\left(x, e_{1}, w\right) \& \text { believe_of }\left(x, e, e_{1}, P, w\right)\right]
\end{aligned}
$$

If we evaluate the LF for (87) we find that the following proposition is expressed:

$$
\begin{aligned}
& \lambda w .\left(\exists t<s^{*}\right)(\exists e)\left[\tau(e) \supset t \&\left(\exists e_{1}\right)\left[Q(w)\left(e_{1}\right)\right] \& \text { acquainted }\left(\text { he, } e_{1}, w\right) \&\right. \\
& \text { believe_of }\left(\text { he, } e, e_{1}, \lambda w_{1} \lambda e_{2}\left(\exists t_{1}\right)\left[\tau\left(e_{2}\right) \supset t_{1} \&\right.\right. \\
& \text { stand_at_window } \left.\left.\left.\left(\text { she, } e_{2}, w_{1}\right)\right], w\right)\right]
\end{aligned}
$$

By assumption, $Q$ is the following property: 


$$
Q=\lambda w \lambda e .\left(\exists t<s^{*}\right)[\tau(e) \supset t \& \text { stand_at_window }(\text { she }, e, w)]
$$

Therefore, the proposition is the same as before, and we have an explanation of why we can express simultaneity either by "past under past" or by "present under past".

There are of course other factive verbs than knowing, e.g., the emotive factive. We cannot go into these here. We hope that similar explanations are available. For the time being we conclude that factive verbs do not constitute counterexamples to the sот parameter.

The sот parameter thus provides a nice diagnostics, indicating how the constructions in question should be analysed. Given that Russian is a non-sot language, we have been guided in section [4] by the soт parameter in the following sense: If we have a "present under past", the matrix is likely to act as a verbal quantifier (i.e., a kind of attitude verb). On the contrary, a "past under past" with a simultaneous reading in the strict sense of temporal overlap between the topic times of the matrix and complement is not possible in Russian on the assumption of tense dependency between the complement and the matrix. This is what the sот parameter tells us, and our findings and analysis of perception verbs and factives with a "past under past" indeed confirm that different factors conspire to produce an independent tense interpretation in these cases.

\section{[5] FUTURE EXTENSIONS}

In the study of tense dependencies and subordinate tense, three syntactic environments are particularly interesting:

- Tense in complements

- Tense in relative clauses

- Tense in adverbial clauses

We have only dealt with complement tense in this article, but we intend to further explore the sот parameter with respect to tense dependencies in adjuncts, both relative and adverbial clauses. This issue is less explored in the literature since adjuncts are not syntactically dependent on the matrix in terms of c-command. Indeed, adjunct tense is often independent of the matrix, hence deictic. Still, certain configurations - notably with the verbal quantifier wiLL in English clearly display tense dependency and tense agreement in sot languages.

\section{[6] SUMMARY}

Below, we sum up some of our main claims and findings. 
- The temporal features of finite verbs are licensed through semantic binding by a semantic tense.

- Non-local tense agreement in English complements is licensed by verbal quantifiers such as WILL/WOULD, HAVE and verbs of attitude. The feature transmission is achieved via binding chains that are created by PRO-movement.

- In Russian, no feature transmission across temporal quantifiers is possible. This fact motivates the formulation of the sот parameter, according to which Russian is a non-sot-language.

- There are obvious differences between the English and the Russian tense systems. Russian has no perfect auxiliary HAVE and may therefore require the insertion of a covert past. Another difference is the assumption of a

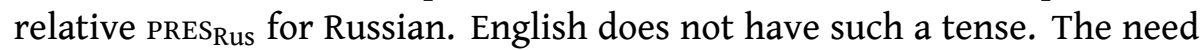
for this local licenser in Russian follows directly from the sот parameter and the requirement that tensed forms have to be licensed by a semantic tense. In English, embedded tenses can be licensed from semantic tenses in the matrix across temporal quantifiers, but this is not possible in Russian.

- Recent objections against the view that Russian is a non-sot-language are refuted by a more careful investigation of the semantics of the verbs involved. Not all verbs with complements are verbal quantifiers.

- Verbs of perception are normally not verbal quantifiers and therefore not subject to the sот parameter. The syntactic complement serves the purpose to describe the event perceived. There is no temporal subordination.

- Factive verbs like "knowing" are more complicated. There the complement serves two purposes: (a) it describes the res situation, and this description is not subordinated to the main verb; (b) it describes the tenseless property ascribed to the res. The visible complement may relate to the (a) purpose or the (b) purpose. In the first case, the factive behaves like a perception verb and we find "past under past" for simultaneity. In the second case, the factive behaves like a verb of attitude, i.e., a verbal quantifier, and we find "present under past".

\section{ACKNOWLEDGMENTS}

We wish to thank Daniel Altshuler whose comments at various stages of our work forced us to work really hard. 


\section{REFERENCES}

Abusch, Dorit. 1994a. Generalizing tense semantics for future contexts. In S. Rothstein (ed.), Events and grammar, 13-33. Dordrecht: Kluwer.

Abusch, Dorit. 1994b. Sequence of tense revisited: Two semantic accounts of tense in intensional contexts. In H. Kamp (ed.), Ellipsis, tense and questions, Dyana-2 Esprit Basic research Project 6852.

Abusch, Dorit. 1997. Sequence of Tense and Temporal de re. Linguistics and Philosophy 20(1). 1-50.

Altshuler, Daniel. 2004. A simultaneous perception of things: SOT in Russian. Snippets 8. 5-6.

Altshuler, Daniel. 2008. Narrative progression effects in Russian indirect reports and what they reveal about the meaning of the past tense. In T. Friedman \& S. Ito (eds.), Proceedings of Semantics and Linguistic Theory 18, Cornell University: CLC Publications.

Altshuler, Daniel. this volume. Aspect in English and Russian flashback discourses. In A. Grønn \& I. Marijanovic (eds.), Russian in contrast, vol. 2(1) Oslo Studies in Language, University of Oslo.

Bary, Corien. 2009. Aspect in Ancient Greek. Radbout Universiteit Nijmegen: Ph. D. Thesis.

Chomsky, Noam. 1995. The minimalist program. Cambridge, MA: MIT Press.

Deo, Ashwini. 2006. Tense and Aspect in Indo-Aryan Languages: Variation and Diachrony. Stanford University: Ph. D. Thesis.

Dowty, David. 1979. Word Meaning and Montague Grammar: The semantics of verbs and times in generative semantics and in Montague's PTQ Synthese Language Library. Dordrecht: Reidel.

Grønn, Atle. 2003. The Semantics and Pragmatics of the Russian Factual Imperfective. Faculty of Arts, University of Oslo: Doctor Artium Thesis.

Grønn, Atle. 2007. Relative Past and the Syntax-semantics Interface in Russian. In P. Kosta \& L. Schürcks (eds.), Linguistic Investigations into Formal Description of Slavic Languages, 515-528. Peter Lang.

Heim, Irene. 1994a. Comments on Abusch's theory of tense. In H. Kamp (ed.), Ellipsis, tense and questions, 143-170. Dyana deliverable R2.2.B. 
Heim, Irene. 1994b. Puzzling reflexive pronouns in de se reports. Handout from Bielefeld conference.

Heim, Irene. 1997. Tense in compositional semantics: MIT lecture notes.

Heim, Irene. 2005. Features on bound pronouns. Ms.

Heim, Irene \& Angelika Kratzer. 1998. Semantics in Generative Grammar. Malden, Mass.: Blackwell.

Higginbotham, James. 1983. The logic of perceptual reports: An extensional alternative to situation semantics. Journal of Philosophy 80. 100-127.

Iatridou, Sabine. 2000. The grammatical ingredients of counterfactuality. Linguistic Inquiry 31. 231-270.

Katz, Graham. 2002. Tense Selection and the Temporal Interpretation of Complement Clauses. In Proceedings of Sinn und Bedeutung VI, 169-184. Konstanz.

Khomitsevich, Olga. 2007. Dependencies Across Phases. From Sequence of Tense to Restrictions on Movement: Utrecht dissertation.

Klein, Wolfgang. 1994. Time in language. London: Routledge.

Kratzer, Angelika. 1990. How specific is a fact? In Proceedings of the 1990 conference on theories of partial information, University of Texas at Austin.

Kratzer, Angelika. 1998. More Structural Analogies Between Pronouns and Tenses. In D. Strolovitch \& A. Lawson (eds.), Proceedings of SALT VIII, Cambridge, Mass.: Ithaca. CLC-Publications.

Kusumoto, Kiyomi. 1999. Tense in embedded contexts: University of Massachusetts at Amherst: Ph. D. dissertation.

Lewis, David. 1979. Attitudes De Dicto and De Se. The Philosophical Review 88. 513-543.

Ogihara, Toshiyuki. 1989. Non-factual before and Adverbs of Quantification. In M. Galloway \& T. Simons (eds.), Proceedings of SALT V, Ithaca: Cornell University Press.

Ogihara, Toshiyuki. 1996. Tense, attitudes, and scope. Dordrecht: Kluwer.

Partee, Barbara H. 1973. Some structural analogies between tenses and pronouns in English. Journal of Philosophy 70(18). 601-609. 
Paslawska, Alla \& Arnim von Stechow. 2003. Perfect Readings in Russian. In M. Rathert, A. Alexiadou \& A. von Stechow (eds.), Perfect explorations, Berlin: Mouton de Guyter.

Schlenker, Philippe. 1999. Propositional attitudes and indexicality: A cross-categorial approach: MIT dissertation.

von Stechow, Arnim. 1981. Indexicals in De Se Contexts.

von Stechow, Arnim. 1995. On the Proper Treatment of Tense. In T. Galloway \& M. Simons (eds.), Proceedings from Semantics and Linguistic Theory V, 362-86. Cornell University.

von Stechow, Arnim. 2003. Feature Deletion under Semantic Binding: Tense, Person and Mood under Verbal Quantifiers. In M. Kadowaki \& S. Kawahara (eds.), Nels, vol. 33, 397-403. Amherst: GLSA.

von Stechow, Arnim. 2005. Semantisches und morphologisches Tempus: Zur temporalen Orientierung von Einstellungen und Modalen. Neue Beiträge zur Germanistik 4(2). 9-54.

von Stechow, Arnim. 2009. Tenses in compositional semantics. In W. Klein \& P. Li (eds.), The expression of time in language, vol. 30, 129-166. Berlin: Mouton de Gruyter.

von Stechow, Arnim \& Max Cresswell. 1982. De Re Belief Generalized. Linguistics and Philosophy 5. 503-535.

Zeijlstra, Hedde. 2004. Sentential negation and negative concord: Utrecht dissertation.

AUTHOR CONTACT INFORMATION

Atle Grønn

Department of Literature, Area Studies and European Languages

University of Oslo

Norway

atle.gronn@ilos.uio.no

Arnim von Stechow

D-78463 Konstanz

St. Stephansplatz 18

Germany

arnim.stechow@me.com 